\title{
Petro-Geochemistry, Genesis and Economic Aspect of Syenitic and Mafic Rocks in Mindif Complex, Far North Cameroon, Central Africa
}

\section{Nguo Sylvestre Kanouo ${ }^{*}$, Lianxun Wang2, Arnaud Patrice Kouske ${ }^{3}$, Syprien Bovari Yomeun², Emmanuel Archelaus Afanga Basua ${ }^{2}$}

\author{
${ }^{1}$ Mineral Exploration and Ore Genesis Unit, Department of Mining Engineering and Mineral Processing, Faculty of Mines and \\ Petroleum Industries, University of Maroua, Maroua, Cameroon \\ ${ }^{2}$ School of Earth Sciences, China University of Geosciences, Wuhan, China \\ ${ }^{3}$ Department of Civil Engineering, The University Institute of Technology, University of Douala, Douala, Cameroon \\ Email: *sylvestrekanouo@yahoo.fr
}

How to cite this paper: Kanouo, N.S., Wang, L., Kouske, A.P., Yomeun, S.B. and Basua, E.A.A. (2019) Petro-Geochemistry, Genesis and Economic Aspect of Syenitic and Mafic Rocks in Mindif Complex, Far North Cameroon, Central Africa. International Journal of Geosciences, 10, 1081-1114. https://doi.org/10.4236/ijg.2019.1012062

Received: June 16, 2019

Accepted: December 6, 2019

Published: December 9, 2019

Copyright $\odot 2019$ by author(s) and Scientific Research Publishing Inc. This work is licensed under the Creative Commons Attribution International License (CC BY 4.0).

http://creativecommons.org/licenses/by/4.0/

\begin{abstract}
Syenitic and mafic rocks in Mindif Complex (Far North of Cameroon) were surveyed and characterized to classify them, understand their formation history, and assess their economic interest. Syenitic bodies (hololeucocratic microsyenites; mesocratic aplitic quartz-syenite; leucocratic porphyritic quartz-biotite syenite, and leucocratic porphyritic biotite-syenite) are silica-oversaturated to silica-saturated, alkaline, and metaluminous. Hololeucocratic microsyenites are structural oriented rocks, cooled in shallow depth from low trace and REE dry residual alkaline melts. Mesocratic aplitic quartz-syenite also crystallized in shallow depth from a much Ba-rich less dry residual melt. Leucocratic porphyritic quartz-biotite and biotite syenitic stocks represent two different rock types cooled from hydrous-rich melts in deep seated environments. The Mindif syenites probably crystallized in crustal source magmas (with important alkali feldspar accumulation) from partial melting of pre-existing igneous protoliths. Medium to coarse-grained-peraluminous granite found at the edge of pink microsyenitic dykes (in contact with granite host), is probably a crystallized product from magmatic mixture between the intrusive syenitic melt and a melt from partial fusion of the granite host rock. Mafic igneous rocks in Mindif are peridotgabbro and gabbro with different characteristics. Peridotgabbro, alkaline, holomelanocratic, medium-grained and ultrabasic, is an REE and incompatible elements depleted rock crystallized in shallow depth from a more evolved mantle source magma with plagioclase accumulation. Tholeiitic gabbro, melanocratic, and also medium-grained, was cooled in shallow depth, from a
\end{abstract}


low-K and slightly LILE-enrichment magma probably originated from partial melting ultradepleted mantle source in sub-duction environment. Syenites and peridotgabbro with their high aluminum content (up to $18.5 \mathrm{wt} \%$ ) greater than that of many parent rocks of lateritic bauxite in Cameroon, can be good parent rocks for bauxite-rich soils if found in a plateau topography and hot-humid tropical climate. The geochemical features of Mindif syenites are close to that of some syenites mined and used as raw materials in ceramic and glass industries. This similarity shows that these syenites are good for glass and ceramic manufacture.

\section{Keywords}

Cameroon, Mindif Complex, Alkaline Rock, Characterization, Petrogenesis, Economic Aspect

\section{Introduction}

Syenites are hololeucocratic to leucocratic intermediate, and rarely mesocratic igneous rocks, formed from cooling of a crustal or mantle source silica-saturated to silica under-saturated magma [1] [2] [3] [4]. Found in various magmatic terrains, or associated to some metamorphic rocks, syenites (with textural differences) can form: plutons, veins, lenses, and/or pockets hosted by their parent rocks or a country rock of a different composition [5] [6] [7]. Syenitic plutons either form discordant bodies (cross-cutting a country rock: stocks, dykes and dykelets) or concordant bodies (intruded parallel to host rocks: sills) [5] [6] [7]. Syenite's textures range from fine to coarse-grained, porphyritic and even pegmatitic; features highly related to their environment and depth of formation [1] [3] [8] [9]. The features presented above are useful for identification and differentiation of a syenitic rock, and, can also help to understand the condition under which these rocks were formed. Syenites present distinctive petrography and geochemical features; important in differentiating them and their characterization. They are also useful in constraining their crystallization history including petrogenesis and tectonic setting [2] [3] [4] [10] [11].

Syenitic rocks are very good in mining and processing industries as they can host gemstones and ore minerals [9] [12] [13] [14] [15] [16], or can enrich soil profiles with some minable metallic elements [17]. They can also be mined as industrial mineral or raw material for some industries [18] [19] [20]. Gem quality corundum was found in some syenites (e.g., sapphire-host syenite xenoliths in Cerova Mountains, Slovakia: [18]; corundums in syenite pegmatites from the Ilmen Mountains, South Urals, Russia: [15]). Interesting values of rare earth elements were reported in the Misery syenitic intrusion, Northern Québec, Canada [21], and in Maoniuping carbonatite-syenite complex, Sichuan Province, China [12]. Gold mineralizations were found in Young-Davidson syenites, Matachewan, Ontario [14] and at Abitibi belt syenites in Canada [22]. Iron ore de- 
posits were characterized in syenites found in Greenland [23]. Uranium ore deposits were characterized in agpaitic nepheline syenites in Ilimaussaq Complex, Greenland [13]. Indirectly, syenites (example nepheline syenites) are the bedrock and parent rock of bauxite at Passa Quatro, Minais Gerais, Brazil [17]. Thus, the study of syenites can guide the prospection of aluminum deposits, as some with high aluminum content, under a dry and humid tropical climate, and plateau topography can produce bauxite-rich soils [17]. Nepheline syenites are mined and used as raw materials in ceramic and glassy industries (e.g., red syenites at the Pilanesberg Complex, South Africa: [24]) and as raw material for alumina production in Russia [20]. Thus, characterizing syenitic rocks in Greenfields can be of great economic interests.

Uncharacterized syenitic complex is found in Mindif at about $10 \mathrm{~km}$ SE of Maroua, Far North Region, Cameroon (Figure 1(c) adapted from [25] and [26]). Rocks in this complex are still not well characterized as limited information is available on them. Their type is still not differentiated, and the geological conditions under which these rocks were formed are still to be elucidated. Additionally, their economic interest is still to be assessed. In this paper, we used field geology, petrographic studies and element geochemical analyses to: 1) characterize and classify rocks found in the Mindif syenitic complex; 2) understand their formation history; and 3) assess their economic potential.

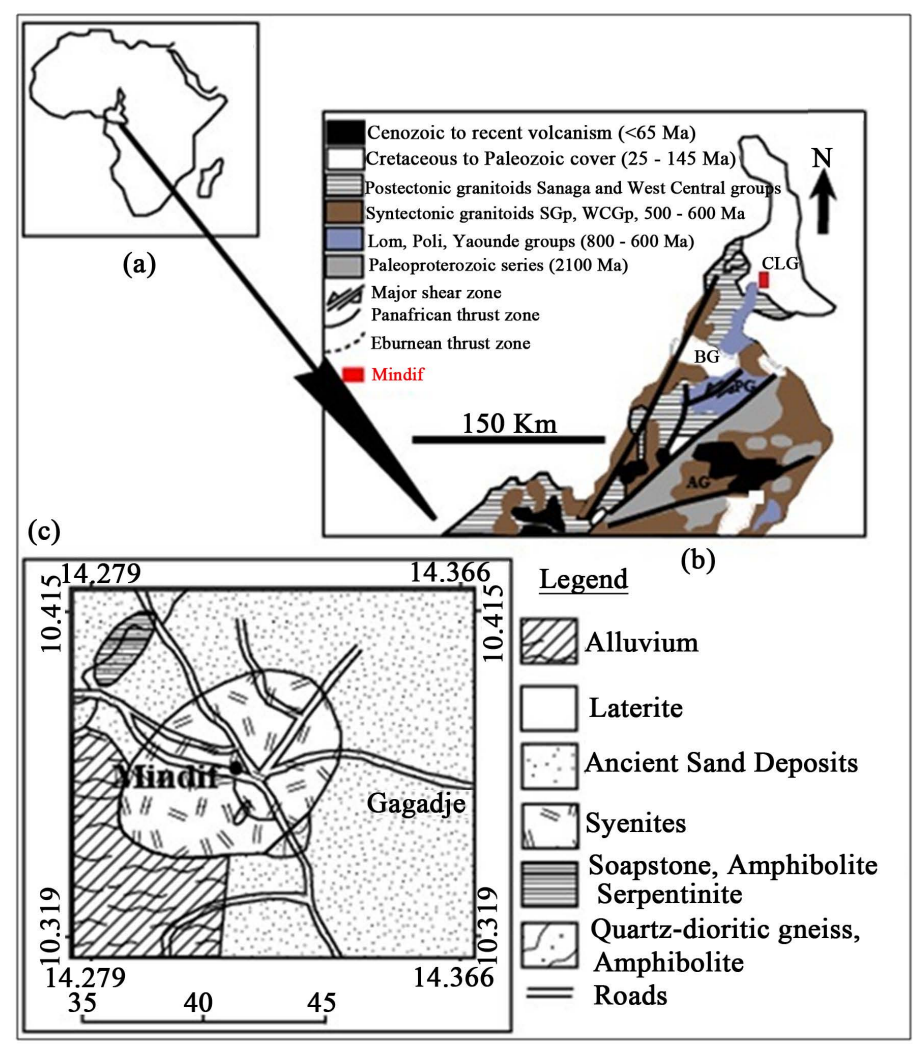

Figure 1. Sketch geologic maps locating the study area within the local and regional settings (with data from [25] and [26]) (CLG: Chad Lake Group; BG: Benue Group); SGp (PG: Poli Group; AG: Adamawa Group; WCG: West Cameroon Group). 


\section{Geography and Geological Settings}

The Far North Region of Cameroon is made of high and low lands. The high lands are mountainous or form isolated inselbergs. Mountainous topographies are found in the West and SW of the region, precisely, in Kapsiki Plateau (altitude: $1000 \mathrm{~m}$ ), and part of the Mandara Mountains [27]. Spots and isolated hills (forming inselbergs) are found in the south and southeast, with some of them located in Mindif, Moutourwa, Lara, and Boboyo. The North and a great portion in the East of the region are low.

The Far north of Cameroon is composed of three main geological units (Figure 1(b)): 1) Quaternary deposits found in Lake Chad Basin and many other parts of the region [28] [29] [30] [31]; 2) volcanic to sub-volcanic complexes related to the Cameroon Volcanic Line [27] [31] [32]; and 3) igneous and metamorphic rocks of the Pan-African Cameroon Mobile Belt [25] [33]. Quaternary materials, mainly found in low lands, are visible in the north and in the east. Some were deposited in and along many rivers (e.g., Mayo Diamaré, Mayo Kani, Mayo Danay, Mayo Tsanaga, Mayo Boula, Logone and Chari). These materials are mostly made up of alluvial and lake-type clay deposits [25] [28] [29] [34], and alluvial and ancient sands [25]. Supergenes deposits were developed on gabboic rocks [30], soapstones, gneisses, migmatites, syenites, and granitoids [25]. Volcanic and sub-volcanic rocks are dominantly found at the Kapsiki Plateau, although, spots are found at hilly reliefs around the town of Maroua. Kapsiki Plateau, the northernmost volcanic structure of the Cameroon Volcanic Line [35], is an asymmetrical horst which covers an area of $150 \mathrm{~km}^{2}$ and lies along the Cameroon-Nigeria border [25]. The volcanic rocks in this plateau are alkaline trachytes and basalts, and perakaline rhyolites [36] [37]. Ankaramites, phonolites, and hawaiite are also found [27]. The magmatic and metamorphic rocks forming the basement in the Far North region of Cameroon vary from one locality to another. Around Kapsiki Plateau, they are assumed Precambrian age migmatites and anatectites; intruded by granites, and cut or overlain by trachytic, rhyolitic, and phonolitic plugs, basaltic necks or flows [27]. The basements rocks in other areas in this region are gneisses, amphibolites, schistes, soapstones, diorites and/or granitoids locally overlain or cut by basaltic flows, dykes or granitic and syenitic stocks [25] [33]. Mindif in the South East of Maroua is dominantly covered by superficial materials (laterites, ancient sands, recent alluviums) partly overlying, gneisses, amphibolites, and soapstones [25]. Part of these rocks is intruded by undifferentiated and undated syenitic inselbergs (with height exceeding $550 \mathrm{~m}$ ) and various domes.

\section{Field Work and Analytical Methods}

Geological survey and characterization of syenitic bodies and mafic rocks were carried out in Mindif. Located outcrops were described based on the following parameters: color, texture and structure, mode of occurrence, mineralogical composition, the existence of specific features (dykes, veins, veinlets, lens, pock- 
ets, and xenoliths) and relationship. More than 50 samples were collected on a total of 30 located outcrops. The collected samples were macroscopically described, thin-sectioned and microscopically characterized, and geochemical analyzed. Thin sections were prepared and observed at the Institute of Geology and Mining Research (IGMR) in Yaoundé, Cameroon. Rock powders of 10 samples ( 7 felsic and 3 mafic rocks) were prepared and their major, minor, trace and rare earth element contents determined in China. Sample preparation and analytical procedures are similar to those presented in [38]. Fresh rock samples were cleaned with deionized water, and subsequently crushed and powdered with an agate mill. Major and minor elements were determined using a ME-XRF26d spectrometer at Australia Laboratory Services (ALS) Co. Ltd. (ALS, Guangzhou, China). The relative standard deviations are $<5 \%$ and the detection limits are $<$ $0.01 \%$. Trace and rare earth elements (REE) abundances were measured by means of ICP-MS (Agilent 7700e) at Sample Solution Co. Ltd. (Wuhan, China). Accuracy and precision of this method were checked by repeated analyses of several reference materials which show a relative standard deviation of $<5 \%$ for REE and $<12 \%$ for other trace elements.

\section{Results}

Field and petrographic data for each rock type are presented separately after its nomenclature and classification. The major, minor, trace and rare earth element composition of those rocks are also presented.

\subsection{Nomenclature and Rock Classification}

Plotted data in $\mathrm{SiO}_{2}$ versus $\mathrm{Na}_{2} \mathrm{O}+\mathrm{K}_{2} \mathrm{O}$ diagram of [39] (Figure 2) distinguish: syenites, gabbro, peridotgabbro and granite. Syenites are all plotted in alkaline field, and contact granite, on alkaline-sub-alkaline dividing line. Gabbro and peridotgabbro are plotted in sub-alkaline and alkaline field, respectively.

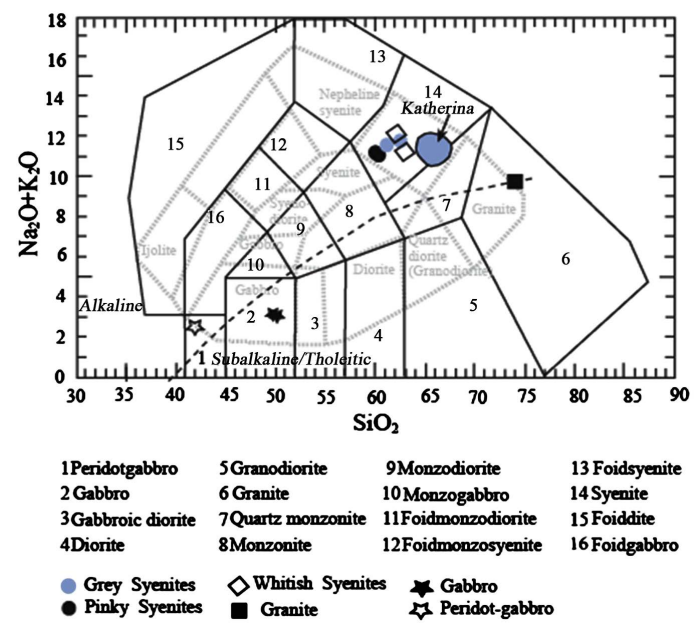

Figure 2. Plots binary diagrams classifying felsic and mafic rocks of $\mathrm{Mindif}$ in $\mathrm{SiO}_{2}$ versus $\mathrm{Na}_{2} \mathrm{O}+\mathrm{K}_{2} \mathrm{O}$ diagram of [39]: (a) diagram with no dividing line (b) with alkalinesub-alkaline dividing line. 


\subsection{Fields Relationships and Petrography}

Field features and microscopic data characterizing syenites, granite, gabbro, peridotgabbro and amphibolite are presented separately in two main groups.

\subsubsection{Syenites and Contact Granite}

Syenites show color, textural, structural, spatial and compositional differences. They are whitish, light-grey, dark-grey, or pink in color. Whitish syenite cropping at the center and north of the area, are leucocratic and locally encloses mafic xenoliths. It locally forms domes, sub-rounded to well-rounded large fragments (Figure 3(a)). This rock is very coarse-grained to porphyritic and mainly composed of alkali feldspars. The alkali feldspar is dominantly microcline with distinctive cross-hatch twinning (Figure 4(a)), and few exsolutions and sericite. Other minerals are few plagioclase and biotite. Very few clinopyroxene, amphibole, muscovite, zircon, opaque minerals and quartz are also found. Biotite flakes mainly form aggregate in contact with some amphibole, clinopyroxene, muscovite, anhedral quartz or opaque minerals. Prismatic zircon crystals occur as inclusion in some large microcline laths.
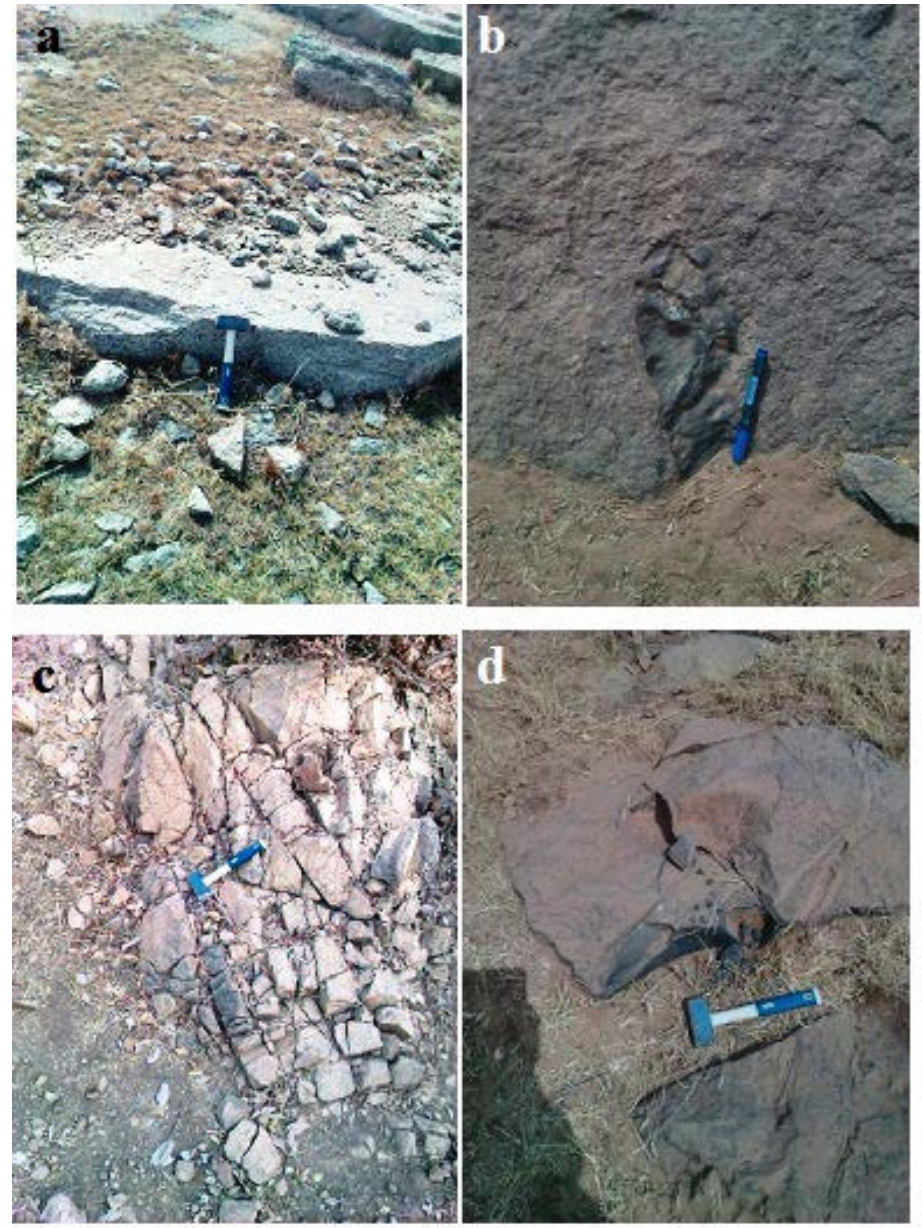

Figure 3. Felsic and mafic outcrops in Mindif ((a) whitish syenite; (b) light grey-syenite with mafic xenoliths; (c) pink syenitic dyke, and (d) peridotgabbro). 


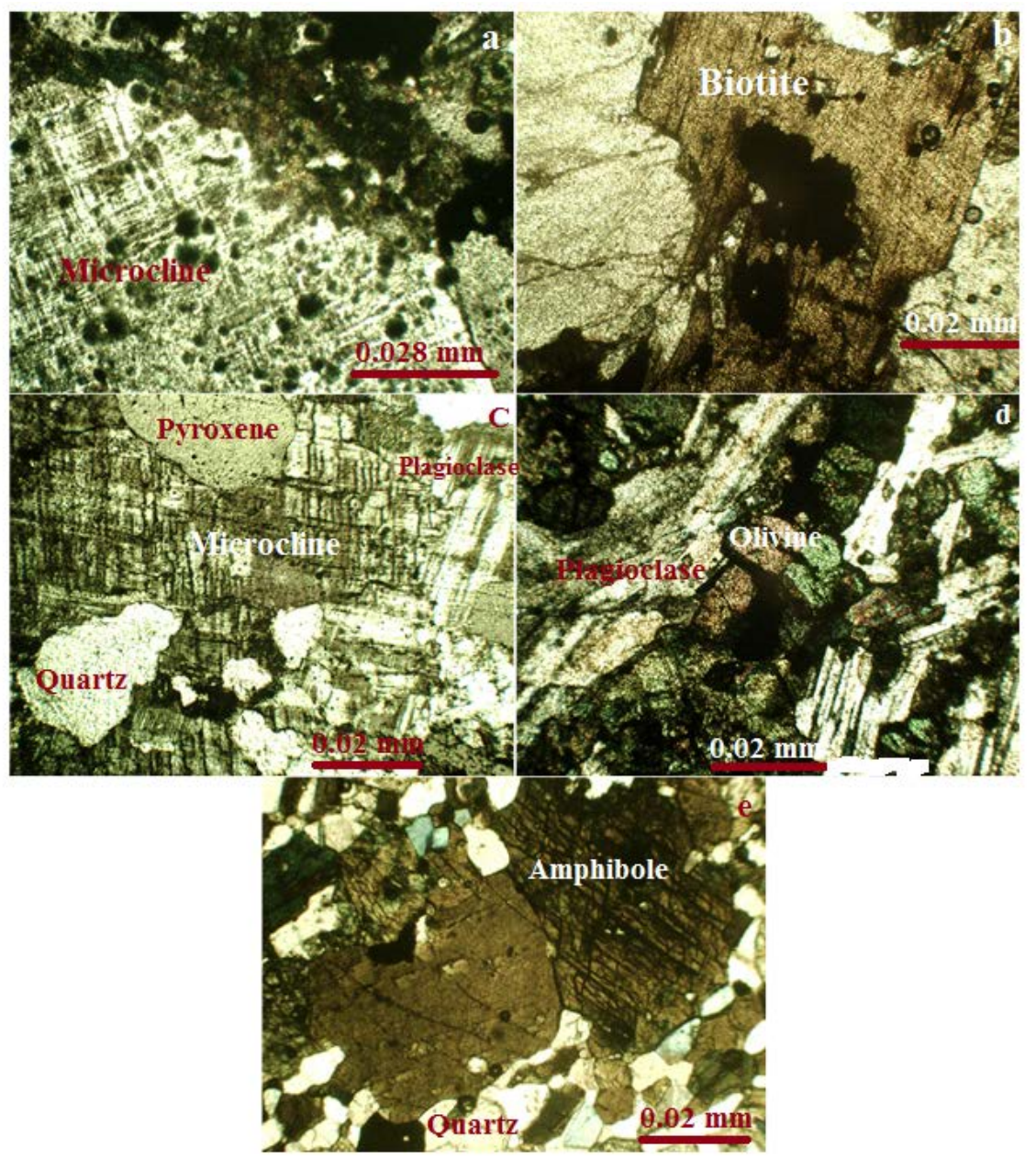

Figure 4. Microphotographs for Mindif felsic and mafic rocks ((a) whitish syenite, (b) light-grey syenite, (c) pink syenite, (d) peridotgabbro and (e) amphibolite schist).

Light-grey syenite also forms domes and sub-rounded to rounded very large blocks in the south and eastern part of the locality. Some blocks enclose mafic xenoliths (similar to those found in whitish syenite) (Figure 3(b)). This leucocratic rock is coarse-grained to porphyritic. It is mainly composed of microcline and few plagioclases. Very few biotite (Figure 4(b)), clinopyroxene, zircon and opaque minerals are found. Clinopyroxene, opaque minerals and biotite are dominantly found together. Zircon crystals prismatic to pyramidal in shape, occurs as inclusion in biotite. The proportion of microcline and biotite is less than those found in whitish syenite.

Dark-grey syenite cropping in the west of the study area, is a mesocratic and quartz-bearing; partly underlying a porphyritic very coarse-grained, sheet-like and highly altered granitic cover rock. It is medium-grained and mainly consists of orthoclase (with few sericite or perthitic texture) and plagioclase. Few biotite and clinopyroxene are associated to very few quartz, titanite and opaque minerals. Orthoclase laths are generally larger than that of plagioclase. Sericite, visible in some orthoclase, locally forms micro-veinlets. 
Pink syenites (Figure 3(c)) (found in the west), are hololeucocratic (no visible ferromagnesian minerals), highly fractured, and form dykes. They cut across highly weathered granitic country rock (similar to the one underlying dark-grey and whitish syenite). The main directions of those syenitic dykes are N60E90, N120E90, and N40E60SE. The composition and grain size change towards the contact with the wall-rock. They are fine-grained ( $\leq 1 \mathrm{~mm}$ in size) in the core, but, medium-grained towards a granitic transitional rock linking the pink syenite with the host rock. Pink syenite is composed of plagioclase, and microcline, and orthoclase (with sericitization), and few muscovite. The contact granite is hololeucocratic, medium to coarse-grained rock with textural zoning. It is coarse-grained at the contact with the country rock and medium-grained close to pink syenite. It is mainly made of quartz and microcline with few plagioclases (Figure 4(c)). Mineral's size increases towards the granitic host rock.

\subsubsection{Peridotgabbro, Gabbro and Amphibolite}

Peridotgabbro found in the east of the area, is very dark in color and holomelanocratic (Figure 4(d)). This rock locally encloses few felsic to greenish veinlets probably product of fluid's circulation. It is dominantly composed of long plagioclase laths associated with olivine crystals (euhedral to well-rounded) (Figure $4(\mathrm{c})$ ). Few orthopyroxene and clinopyroxene with sub-hedral to euhedral shape are found. Part of the olivine crystals encloses regular to irregular cracks, or fine-grained crystals of the same mineral. Few anhedral to euhedral opaque minerals occurs at the contact with some olivine crystals. Gabbro found in the south-east of the study area is dark-grey, melanocratic, and have no clearly defined shape. It is medium-grained and composed of clinopyroxene, orthopyroxene, plagioclase, and few opaque minerals.

Amphibolite is a melanocratic and pneumato-granoblastic rock outcropping in the east of the area. This rock is weakly-schistose "amphibolite schist" with its features similar to those of xenoliths found in light-grey and whitish syenites. This rock is medium-grained and mainly consists of brownish amphibole crystals. These crystals (sub-hedral to euhedral) are mainly aligned (parallel to SW-NE direction). Few amphibole crystals are associated with sub-rounded to anhedral quartz in quartz-rich alignments. Sub-hedral clinopyroxene and very few plagioclase laths are spotted in quartz-rich alignments. Opaque minerals are found in both amphibole-rich and quartz-rich parts.

\subsection{Geochemistry}

Major and minor elements (in oxide) abundance and CIPW norms (Table 1) are presented for each rock types (syenites, contact granite, gabbro, and peridotgabbro). Trace and rare earth elements contents and calculated values for same rocks are also presented (Table 2).

\subsubsection{Syenites and Contact Granite}

1) Major and Minor Elements 
N. S. Kanouo et al.

Table 1. Major element in oxide (wt\%) and CIPW norms for syenitic and mafic rocks from Mindif.

\begin{tabular}{|c|c|c|c|c|c|c|c|c|c|c|}
\hline \multirow{2}{*}{$\begin{array}{l}\text { Rock type composition } \\
\text { (wt } \%)\end{array}$} & \multicolumn{2}{|c|}{ Grey syenite } & \multicolumn{2}{|c|}{ Pinky syenites } & \multicolumn{2}{|c|}{ Whitish syenites } & \multirow{2}{*}{$\begin{array}{c}\begin{array}{c}\text { Contact } \\
\text { granite }\end{array} \\
\text { MDF8 }\end{array}$} & \multicolumn{2}{|c|}{ Gabbro } & \multirow{2}{*}{$\begin{array}{c}\text { Peridotgabbro } \\
\text { MDF12 }\end{array}$} \\
\hline & $\begin{array}{c}\text { Dark-grey } \\
\text { MDF1 }\end{array}$ & $\begin{array}{l}\text { Light-grey } \\
\text { MDFp1 }\end{array}$ & MDF13 & MDF6 & MDF20 & MDF23 & & MDF4 & MDF22 & \\
\hline $\mathrm{SiO}_{2}$ & 62.67 & 61.30 & 60.08 & 60.42 & 62.23 & 63.09 & 74.00 & 49.82 & 49.95 & 42.08 \\
\hline $\mathrm{TiO}_{2}$ & 0.89 & 0.82 & 1.02 & 1.02 & 0.90 & 0.87 & 0.04 & 1.68 & 1.71 & 1.71 \\
\hline $\mathrm{Al}_{2} \mathrm{O}_{3}$ & 17.59 & 18.43 & 18.13 & 18.22 & 17.79 & 17.48 & 13.72 & 13.60 & 14.09 & 15.83 \\
\hline $\mathrm{Fe}_{2} \mathrm{O}_{3}{ }^{\mathrm{t}}$ & 3.71 & 3.34 & 4.16 & 4.16 & 3.43 & 3.48 & 0.80 & 13.41 & 12.93 & 16.89 \\
\hline $\mathrm{MnO}$ & 0.09 & 0.08 & 0.10 & 0.10 & 0.07 & 0.08 & 0.03 & 0.16 & 0.16 & 0.27 \\
\hline $\mathrm{MgO}$ & 0.73 & 0.71 & 0.97 & 0.97 & 0.79 & 0.76 & 0.08 & 9.10 & 8.63 & 9.29 \\
\hline $\mathrm{CaO}$ & 1.71 & 2.43 & 2.75 & 2.83 & 1.82 & 2.20 & 0.46 & 9.05 & 9.04 & 10.79 \\
\hline $\mathrm{Na}_{2} \mathrm{O}$ & 5.33 & 5.25 & 5.17 & 5.18 & 5.02 & 4.90 & 2.90 & 2.73 & 2.82 & 2.15 \\
\hline $\mathrm{K}_{2} \mathrm{O}$ & 6.34 & 6.26 & 5.95 & 5.87 & 6.98 & 6.23 & 6.82 & 0.35 & 0.37 & 0.39 \\
\hline $\mathrm{P}_{2} \mathrm{O}_{5}$ & 0.25 & 0.25 & 0.30 & 0.30 & 0.24 & 0.27 & 0.01 & 0.17 & 0.18 & 0.03 \\
\hline LOI & 0.22 & 0.25 & 0.52 & 0.40 & 0.27 & 0.16 & 0.49 & 0.00 & 0.00 & 0.00 \\
\hline Total & 99.53 & 99.12 & 99.13 & 99.46 & 99.54 & 99.55 & 99.34 & 100.06 & 99.87 & 99.43 \\
\hline $\mathrm{Na}_{2} \mathrm{O}+\mathrm{K}_{2} \mathrm{O}$ & 11.67 & 11.51 & 11.12 & 11.05 & 11.10 & 11.13 & 9.72 & 3.08 & 3.19 & 2.54 \\
\hline $\mathrm{Al}_{2} \mathrm{O}_{3} / \mathrm{TiO}_{2}$ & 19.76 & 22.48 & 17.77 & 17.86 & 19.77 & 20.09 & 343 & 8.10 & 8.24 & 9.26 \\
\hline $\mathrm{Na}_{2} \mathrm{O} / \mathrm{K}_{2} \mathrm{O}$ & 0.84 & 0.84 & 0.87 & 0.88 & 0.72 & 0.79 & 0.43 & 7.8 & 7.6 & 5.5 \\
\hline$\left(\mathrm{Na}_{2} \mathrm{O}+\mathrm{K}_{2} \mathrm{O}\right)-\left(0.37 \mathrm{SiO}_{2}-14.43\right)$ & 2.91 & 3.28 & 3.32 & 3.12 & 3.40 & 2.22 & -3.23 & -0.92 & -0.86 & 1.40 \\
\hline $\mathrm{Na}_{2} \mathrm{O}+\mathrm{K}_{2} \mathrm{O} / \mathrm{Al}_{2} \mathrm{O}_{3}$ & 0.66 & 0.62 & 0.61 & 0.61 & 0.67 & 0.64 & 0.71 & 0.23 & 0.23 & 0.16 \\
\hline $\mathrm{CaO}+\mathrm{Na}_{2} \mathrm{O}+\mathrm{K}_{2} \mathrm{O}$ & 13.38 & 13.94 & 13.87 & 13.88 & 13.82 & 13.33 & 10.18 & 12.13 & 12.23 & 13.33 \\
\hline Mg\# & 24.89 & 26.36 & 26.20 & 26.20 & 27.94 & 22.94 & 12.06 & 53.33 & 52.92 & 48.26 \\
\hline \multicolumn{11}{|c|}{ CIPW Norms (wt\%) } \\
\hline Quartz & 1.97 & - & - & - & 0.84 & 4.50 & 29.84 & - & - & - \\
\hline Orthose & 37.70 & 37.40 & 35.00 & 35.00 & 41.53 & 37.03 & 40.76 & 2.06 & 2.19 & 2.31 \\
\hline Albite & 45.38 & 44.91 & 44.22 & 44.22 & 42.76 & 41.70 & 24.82 & 23.04 & 23.85 & 7.54 \\
\hline Anorthite & 5.38 & 8.32 & 9.21 & 9.21 & 5.43 & 7.34 & 2.24 & 23.76 & 24.68 & 32.50 \\
\hline Nepheline & - & - & - & - & - & - & - & - & - & 5.80 \\
\hline Diopside & 1.28 & 1.88 & 2.52 & 2.52 & 1.75 & 1.57 & - & 16.35 & 15.57 & 17.39 \\
\hline Hypersthene & 4.99 & 4.59 & 4.47 & 4.47 & 4.47 & 4.62 & 1.20 & 18.69 & 18.73 & - \\
\hline Olivine & - & 0.09 & 1.13 & 1.13 & - & - & - & 9.96 & 8.84 & 27.88 \\
\hline Magnetite & 1.01 & 0.65 & 0.80 & 0.80 & 0.94 & 0.95 & 0.28 & 2.56 & 2.48 & 3.25 \\
\hline Ilmenite & 1.70 & 1.57 & 1.95 & 1.95 & 1.72 & 1.66 & 0.08 & 3,18 & 3,25 & 3.26 \\
\hline Corindon & - & - & - & - & - & - & 0.76 & - & - & - \\
\hline Apatite & 0.58 & 0.59 & 0.70 & 0.70 & 0.56 & 0.63 & 0.02 & 0.39 & 0.42 & 0.07 \\
\hline TOTAL & 100.00 & 100.00 & 100.00 & 100.00 & 100.00 & 100.00 & 100.00 & 100.00 & 100.00 & 100.00 \\
\hline
\end{tabular}

$\mathrm{Mg} \#=100 \times(\mathrm{MgO} / 40.31) /(\mathrm{MgO} / 40.31)+\mathrm{Fe}_{2} \mathrm{O}_{3} \times 0.8998 /\left(71.85 \times(1-0.15)\right.$, assuming $\mathrm{Fe}_{2} \mathrm{O}_{3} /\left(\mathrm{Fe}_{2} \mathrm{O}_{3}+\mathrm{FeO}\right)=0.15$. Recalculated to $100 \%$ anhydrous; total iron is expressed as $\mathrm{Fe}_{2} \mathrm{O}_{3}$; LOI: Loss on ignition. 
Table 2. Trace and rare earth element abundance (in ppm) for syenitic and mafic rocks from Mindif.

\begin{tabular}{|c|c|c|c|c|c|c|c|c|c|c|}
\hline \multirow{2}{*}{$\begin{array}{l}\text { Rock type } \\
\text { composition } \\
\text { (wt\%) }\end{array}$} & \multicolumn{2}{|c|}{ Grey syenites } & \multicolumn{2}{|c|}{ Pink syenites } & \multicolumn{2}{|c|}{ Whitish syenites } & \multirow{2}{*}{$\begin{array}{l}\begin{array}{l}\text { Contact } \\
\text { granite }\end{array} \\
\text { MDF8 }\end{array}$} & \multicolumn{2}{|c|}{ Gabbro } & \multirow{2}{*}{$\begin{array}{c}\text { Peridotgabbro } \\
\text { MDF12 }\end{array}$} \\
\hline & Dark-grey-MDF1 & Light-grey MDFp1 & MDF13 & MDF6 & MDF20 & MDF23 & & MDF4 & MDF22 & \\
\hline $\mathrm{Li}$ & 7.22 & 6.35 & 6.12 & 6.06 & 8.16 & 9.78 & 1.62 & 5.08 & 5.00 & 5.16 \\
\hline $\mathrm{Be}$ & 0.88 & 0.86 & 0.63 & 0.59 & 0.87 & 1.30 & 0.39 & 0.71 & 0.73 & 0.26 \\
\hline $\mathrm{Sc}$ & 8.02 & 7.19 & 9.23 & 10.1 & 6.84 & 7.50 & 0.20 & 23.4 & 22.6 & 47.1 \\
\hline $\mathrm{V}$ & 11.7 & 17.6 & 21.4 & 22.5 & 14.9 & 19.2 & 5.70 & 186 & 181 & 479 \\
\hline $\mathrm{Cr}$ & 0.76 & 1.40 & 1.99 & 1.89 & 1.10 & 1.57 & 1.09 & 294 & 279 & 39.1 \\
\hline Co & 1.82 & 2.59 & 3.27 & 3.37 & 2.09 & 2.86 & 2.55 & 57.0 & 52.5 & 59.0 \\
\hline $\mathrm{Ni}$ & 0.54 & 1.37 & 1.74 & 1.56 & 1.16 & 1.32 & 1.92 & 258 & 230 & 24.1 \\
\hline $\mathrm{Cu}$ & 2.9 & 3.80 & 4.20 & 4.41 & 3.28 & 3.88 & 4.32 & 102 & 102 & 16.6 \\
\hline $\mathrm{Zn}$ & 75.7 & 55.9 & 70.7 & 72.5 & 67.7 & 61.8 & 7.33 & 113 & 105 & 117 \\
\hline $\mathrm{Ga}$ & 22.7 & 21.7 & 20.9 & 21.4 & 21.7 & 21.1 & 20.5 & 18.5 & 19.3 & 16.4 \\
\hline $\mathrm{Rb}$ & 60.7 & 49.7 & 43.4 & 42.6 & 63.0 & 79.9 & 77.6 & 4.60 & 4.89 & 1.98 \\
\hline $\mathrm{Sr}$ & 208 & 351 & 341 & 333 & 168 & 373 & 242 & 249 & 252 & 345 \\
\hline $\mathrm{Y}$ & 22.4 & 15.6 & 20.6 & 20.3 & 18.4 & 18.4 & 1.97 & 19.6 & 20.5 & 15.7 \\
\hline $\mathrm{Zr}$ & 59.8 & 189 & 304 & 348 & 212 & 130 & 32.6 & 102 & 101 & 23.0 \\
\hline $\mathrm{Nb}$ & 20.5 & 15.4 & 16.2 & 16.5 & 18.4 & 18.5 & 0.93 & 8.55 & 9.20 & 1.04 \\
\hline $\mathrm{Ta}$ & 1.05 & 0.76 & 0.84 & 0.83 & 0.95 & 1.03 & 0.043 & 0.49 & 0.52 & 0.065 \\
\hline Sn & 0.99 & 0.68 & 0.63 & 0.66 & 0.91 & 0.85 & 0.18 & 0.95 & 1.01 & 0.48 \\
\hline Cs & 0.26 & 0.15 & 0.13 & 0.12 & 0.25 & 0.46 & 0.16 & 0.26 & 0.28 & 0.076 \\
\hline $\mathrm{Ba}$ & 4067 & 2687 & 2739 & 2622 & 2378 & 2617 & 1041 & 78.2 & 79.3 & 75.4 \\
\hline $\mathrm{Hf}$ & 1.51 & 3.70 & 5.57 & 6.23 & 4.49 & 2.90 & 1.44 & 2.66 & 2.85 & 0.78 \\
\hline $\mathrm{Th}$ & 2.20 & 0.70 & 0.37 & 0.40 & 1.13 & 3.37 & 0.41 & 0.58 & 0.58 & 0.033 \\
\hline $\mathrm{U}$ & 0.46 & 0.24 & 0.15 & 0.17 & 0.40 & 0.87 & 0.25 & 0.20 & 0.20 & 0.021 \\
\hline $\mathrm{Pb}$ & 9.90 & 9.84 & 8.74 & 8.84 & 9.84 & 16.6 & 21.6 & 0.99 & 0.71 & 0.61 \\
\hline $\mathrm{Tl}$ & 0.23 & 0.18 & 0.17 & 0.17 & 0.24 & 0.30 & 0.21 & 0.037 & 0.028 & 0.029 \\
\hline \multicolumn{11}{|c|}{ Rare Earth Element and Calculated Values } \\
\hline $\mathrm{La}$ & 34.5 & 27.0 & 27.7 & 27.8 & 29.0 & 32.9 & 4.94 & 6.32 & 6.70 & 1.57 \\
\hline $\mathrm{Ce}$ & 65.3 & 49.8 & 51.6 & 53.7 & 56.8 & 60.6 & 8.54 & 14.6 & 15.5 & 5.12 \\
\hline $\operatorname{Pr}$ & 8.05 & 5.92 & 6.59 & 6.65 & 7.04 & 7.18 & 0.57 & 2.00 & 2.17 & 0.95 \\
\hline $\mathrm{Nd}$ & 33.7 & 34.5 & 28.5 & 29.2 & 29.5 & 29.0 & 1.72 & 10.1 & 10.4 & 5.55 \\
\hline $\mathrm{Sm}$ & 6.69 & 4.95 & 5.91 & 5.97 & 5.86 & 5.65 & 0.32 & 3.17 & 3.31 & 2.07 \\
\hline $\mathrm{Eu}$ & 6.16 & 5.30 & 5.21 & 5.43 & 5.62 & 4.73 & 0.58 & 1.25 & 1.27 & 0.92 \\
\hline $\mathrm{Gd}$ & 6.02 & 4.31 & 5.45 & 5.48 & 5.06 & 4.50 & 0.25 & 4.34 & 4.32 & 2.78 \\
\hline $\mathrm{Tb}$ & 0.80 & 0.58 & 0.70 & 0.72 & 0.69 & 0.63 & 0.061 & 0.65 & 0.70 & 0.47 \\
\hline Dy & 4.49 & 3.21 & 3.96 & 3.91 & 3.76 & 3.58 & 0.31 & 3.97 & 4.15 & 3.04 \\
\hline Ho & 0.82 & 0.57 & 0.70 & 0.75 & 0.68 & 0.66 & 0.072 & 0.73 & 0.79 & 0.63 \\
\hline
\end{tabular}




\begin{tabular}{|c|c|c|c|c|c|c|c|c|c|c|}
\hline Er & 2.03 & 1.39 & 1.79 & 1.87 & 1.69 & 1.74 & 0.20 & 1.88 & 1.96 & 1.74 \\
\hline $\mathrm{Tm}$ & 0.27 & 0.20 & 0.23 & 0.25 & 0.24 & 0.25 & 0.038 & 0.26 & 0.29 & 0.26 \\
\hline $\mathrm{Yb}$ & 1.62 & 1.15 & 1.33 & 1.43 & 1.35 & 1.43 & 0.19 & 1.51 & 1.62 & 1.54 \\
\hline $\mathrm{Lu}$ & 0.23 & 0.17 & 0.20 & 0.21 & 0.19 & 0.21 & 0.042 & 0.22 & 0.24 & 0.244 \\
\hline \multicolumn{11}{|c|}{ Calculated ratios and anomalies } \\
\hline $\mathrm{Zr} / \mathrm{TiO}_{2}$ & 67.19 & 230.488 & 298.039 & 341.176 & 235.556 & 149.425 & 815.0 & 60.714 & 59.064 & 13.450 \\
\hline $\mathrm{Rb} / \mathrm{Sr}$ & 0.292 & 0.142 & 0.127 & 0.128 & 0.375 & 0.214 & 0.321 & 0.018 & 0.019 & 0.006 \\
\hline $\mathrm{Sr} / \mathrm{Y}$ & 9.286 & 22.5 & 16.553 & 16.404 & 9.130 & 20.271 & 122.843 & 12.704 & 12.293 & 21.975 \\
\hline $\mathrm{Y} / \mathrm{Nb}$ & 1.093 & 1.013 & 1.272 & 1.230 & 1.000 & 0.995 & 2.118 & 2.292 & 2.228 & 15.096 \\
\hline $\mathrm{Th} / \mathrm{U}$ & 4.783 & 2.917 & 2.467 & 2.353 & 2.825 & 3.874 & 1.640 & 2.90 & 2.90 & 1.571 \\
\hline $\mathrm{Zr} / \mathrm{Hf}$ & 39.603 & 51.081 & 54.578 & 55.859 & 47.216 & 44.828 & 22.639 & 38.346 & 35.439 & 29.487 \\
\hline $\mathrm{Ba} / \mathrm{Nb}$ & 198.390 & 174.481 & 169.074 & 158.909 & 129.239 & 141.459 & 119.354 & 9.146 & 8.620 & 72.5 \\
\hline $\mathrm{Nb} / \mathrm{Ta}$ & 19.524 & 20.263 & 19.286 & 19.880 & 19.368 & 17.961 & 21.628 & 17.449 & 17.692 & 16.0 \\
\hline $\mathrm{Nb} / \mathrm{Th}$ & 9.32 & 22.0 & 43.78 & 41.25 & 16.28 & 5.49 & 2.27 & 14.74 & 15.86 & 34.67 \\
\hline $\mathrm{Nb} / \mathrm{U}$ & 44.565 & 61.60 & 108.0 & 97.059 & 46.0 & 21.264 & 3.72 & 42.75 & 46.0 & 49.524 \\
\hline $\mathrm{Th} / \mathrm{La}$ & 0.064 & 0.026 & 0.013 & 0.014 & 0.039 & 0.102 & 0.083 & 0.092 & 0.087 & 0.021 \\
\hline $\mathrm{Ba} / \mathrm{La}$ & 117.884 & 99.519 & 98.881 & 94.317 & 82.0 & 79.544 & 210.729 & 12.373 & 11.836 & 48.025 \\
\hline $\mathrm{La} / \mathrm{Nb}$ & 1.68 & 1.75 & 1.71 & 1.68 & 1.58 & 1.78 & 5.32 & 0.74 & 0.73 & 1.51 \\
\hline $\mathrm{Ce} / \mathrm{Pb}$ & 6.596 & 5.061 & 5.904 & 6.075 & 5.772 & 3.651 & 0.395 & 14.747 & 21.830 & 8.393 \\
\hline$(\mathrm{Ce} / \mathrm{Yb}) \mathrm{N}$ & 10.556 & 11.340 & 10.160 & 9.835 & 11.020 & 11.099 & 11.766 & 2.532 & 2.506 & 0.871 \\
\hline$(\mathrm{La} / \mathrm{Yb}) \mathrm{N}$ & 14.415 & 15.891 & 14.097 & 13.160 & 14.542 & 15.574 & 17.593 & 2.833 & 2.704 & 0.690 \\
\hline$(\mathrm{Tb} / \mathrm{Yb}) \mathrm{N}$ & 2.171 & 2.219 & 2.316 & 2.215 & 2.249 & 1.938 & 1.412 & 1.901 & 1.901 & 1.343 \\
\hline$\Sigma$ LREE & 154.4 & 127.47 & 125.21 & 128.75 & 133.82 & 140.06 & 16.67 & 37.44 & 39.35 & 16.18 \\
\hline$\Sigma$ HREE & 10.99 & 11.73 & 14.36 & 14.62 & 13.66 & 13.0 & 1.18 & 13.56 & 14.07 & 10.744 \\
\hline$\Sigma \mathrm{REE}$ & 165.39 & 139.20 & 139.57 & 143.37 & 147.48 & 153.06 & 17.833 & 51.0 & 53.42 & 26.924 \\
\hline$\Sigma$ LREE/ $\Sigma$ HREE & 14.049 & 10.867 & 8.719 & 8.806 & 9.796 & 10.774 & 14.127 & 2.761 & 2.797 & 1.506 \\
\hline $\mathrm{Eu} / \mathrm{Eu}^{*}$ & 1.958 & 1.936 & 1.916 & 1.963 & 2.040 & 1.764 & 0.753 & 1.054 & 1.033 & 1.30 \\
\hline
\end{tabular}

Considered LREE are from $\mathrm{La}$ to $\mathrm{Eu}$ and HREE, from Gd to $\mathrm{Lu}$. The $\mathrm{Eu} / \mathrm{Eu}^{*}$ was calculated following similar method in $\mathrm{Kamgang}$ et al. (2013) $\mathrm{Eu} / \mathrm{Eu}^{*}=$ $\mathrm{EuN} /(\mathrm{SmN} \times \mathrm{NdN}) 1 / 2$ with $\mathrm{EuN}, \mathrm{SmN}, \mathrm{NdN}$ being chondrite-normalized values of those elements.

The $\mathrm{SiO}_{2}$ contents range from 60 to $63.09 \mathrm{wt} \%$ in syenites, and up to $74 \mathrm{wt} \%$ in contact granite. The highest $\mathrm{SiO}_{2}$ values within syenites are found in dark-grey and whitish syenites and the lowest values $(\approx 60 \mathrm{wt} \%)$ in pink syenites. Within other oxides, $\mathrm{Al}_{2} \mathrm{O}_{3}$ contents (17.48 - $18.43 \mathrm{wt} \%$ ) with slight high values are found in pink and light-grey syenites. The $\mathrm{Fe}_{2} \mathrm{O}_{3}$ abundance is generally less than $4.0 \mathrm{wt} \%$, although a relatively high value (4.16 wt\%) was found in pink syenites, which in contrast, lack ferromagnesian mineral. The $\mathrm{Al}_{2} \mathrm{O}_{3}$ and $\mathrm{Fe}_{2} \mathrm{O}_{3}$ abundances in contact granite are 13.72 and 0.80 , respectively. The $\mathrm{TiO}_{2}(1.02-0.8$ wt $\%), \mathrm{MgO}(0.97-0.71 \mathrm{wt} \%), \mathrm{P}_{2} \mathrm{O}_{5}(0.30-0.24 \mathrm{wt} \%)$ and $\mathrm{MnO}(0.1-0.07 \mathrm{wt} \%)$ 
are much higher in pink syenites, and lower in grey syenites. They do not exceed $0.04 \mathrm{wt} \%$ in contact granite. The calculated $\mathrm{Al}_{2} \mathrm{O}_{3} / \mathrm{TiO}_{2}(17.7-22.48)$ and Mg\# (22.94 - 27.94) for syenites are different from that of granite. The highest $\mathrm{Al}_{2} \mathrm{O}_{3} / \mathrm{TiO}_{2}$ ratios are that of light-grey and whitish syenites which have the lowest $\mathrm{Mg}$ \# values. The $\mathrm{CaO}(1.71-2.83 \mathrm{wt} \%), \mathrm{Na}_{2} \mathrm{O}$ (4.90 - $\left.5.33 \mathrm{wt} \%\right)$, and $\mathrm{K}_{2} \mathrm{O}(5.87-6.98 \mathrm{wt} \%)$ and $\mathrm{Na}_{2} \mathrm{O}+\mathrm{K}_{2} \mathrm{O}(11.7-11.0 \mathrm{wt} \%)$ contents are much compatible with values in alkaline syenites from mantle source magma [4]. These values are generally lower in contact granite. Some calculated values: $\mathrm{Na}_{2} \mathrm{O} / \mathrm{K}_{2} \mathrm{O},\left(\mathrm{Na}_{2} \mathrm{O}+\mathrm{K}_{2} \mathrm{O}\right)-\left(0.37\right.$ * $\left.\mathrm{SiO}_{2}-14.43\right), \mathrm{Na}_{2} \mathrm{O}+\mathrm{K}_{2} \mathrm{O} / \mathrm{Al}_{2} \mathrm{O}_{3}, \mathrm{Na}_{2} \mathrm{O}+$ $\mathrm{K}_{2} \mathrm{O} / \mathrm{Al}_{2} \mathrm{O}_{3}$ and $\mathrm{CaO}+\mathrm{Na}_{2} \mathrm{O}+\mathrm{K}_{2} \mathrm{O}$ range from 0.87 to $0.72,3.34$ to 2.22, 0.66 to 0.61 , and 13.94 to 13.3 , respectively and show some close values. CIPW norms show the presence of quartz (4.5 - $0.8 \mathrm{wt} \%)$ in dark-grey and whitish syenite, olivine in pink and light-grey syenite, and corundum in contact granite. The first two groups of syenites are plotted very close in silica versus oxide diagram (Figure 5).

2) Trace and rare earth elements

Trace element abundances (Table 2) are heterogeneous with some significant and relatively high values. High value's trace elements (in ppm) are Ba (4067 2617), $\operatorname{Sr}(373$ - 208) and $\mathrm{Zr}(348$ - 59.8). These values are greater than those in contact granite (Ba: 1041 ppm, Sr: 242 ppm and Zr: 32.6 ppm). The Rb (80 - 43), $\mathrm{Zn}(76$ - 55), Ga (23 - 20), Y (22.5 - 15.0), Nb (21 - 15) and V (23 - 11) are significantly low. Those of $\mathrm{Pb}, \mathrm{Sc}, \mathrm{Li}, \mathrm{Hf}, \mathrm{Cu}, \mathrm{Co}, \mathrm{Th}, \mathrm{Cr}, \mathrm{Ni}, \mathrm{Be}, \mathrm{Ta}, \mathrm{Sn}, \mathrm{U}$, and $\mathrm{Cs}$ mainly less than $18 \mathrm{ppm}$, are very low. The highest $\mathrm{Ba}, \mathrm{Y}, \mathrm{Nb}, \mathrm{Zn}, \mathrm{Ga}$ and $\mathrm{Th}$ values were quantified in dark-grey syenite which encloses the lowest $\mathrm{Zr}, \mathrm{Cr}, \mathrm{Co}$, $\mathrm{Ni}$, and $\mathrm{Cu}$. Significant concentrations of $\mathrm{Zr}, \mathrm{Cr}, \mathrm{Co}, \mathrm{Ni}$, and $\mathrm{Cu}$ are found in light-grey, whitish, and pink syenites with the later enclosing the highest $\mathrm{Sc}, \mathrm{V}$, $\mathrm{Hf}, \mathrm{Cu}, \mathrm{Co}, \mathrm{Ni}$, and $\mathrm{Cr}$ values. Plots for selected trace elements (Figure 6) are generally scattered with just few closeness. The calculated trace elements ratios in Table $2\left(\mathrm{Zr} / \mathrm{TiO}_{2}: 342\right.$ - 67; $\mathrm{Ba} / \mathrm{Nb}: 199$ - 129; Nb/U: 108 - 21; Zr/Hf: 56 - 39; Sr/Y: 23 - 9; Nb/Ta: 21 - 17; Th/U: 5 - 2; Rb/Sr: $0.3-0.1 ; \mathrm{Y} / \mathrm{Nb}:<1.30$ ) in some cases show extreme variation probably due to the availability of those elements is their source magma.

Rare earth element contents in syenites (Table 2) show the domination of light rare earth elements (LREE) on heavy rare earth elements (HREE). The total REE ( $\Sigma$ REE in ppm) ranges from 166 to 139 with the highest values found in quartz-bearing syenites, and very low values, in contact granite. Quartz-syenites (dark-grey and whitish syenites) with the highest REE contents also enclose the highest $\mathrm{La}(\leq 34.5 \mathrm{ppm})$ and $\mathrm{Ce}(\leq 65.2 \mathrm{ppm})$. In General, lowest REE contents are found in pink and light-grey syenites, although elevated $\mathrm{Nd}$ and Ce contents were found in these two rocks. The calculated $\mathrm{Eu}$ anomalies $\left(\mathrm{Eu} / \mathrm{Eu}^{*}\right)$ are globally close to 2 (pronounced positive anomaly as shown in Figure 7(a) and Figure $8(\mathrm{a}))$. The $(\mathrm{La} / \mathrm{Yb})_{\mathrm{N}},(\mathrm{Ce} / \mathrm{Yb})_{\mathrm{N}}$, and $(\mathrm{Tb} / \mathrm{Yb})_{\mathrm{N}}$ ratios range from 16 to $13,11.4$ to 9.8 and 2.25 to 1.9 , respectively; with all the studied rocks showing LREE 


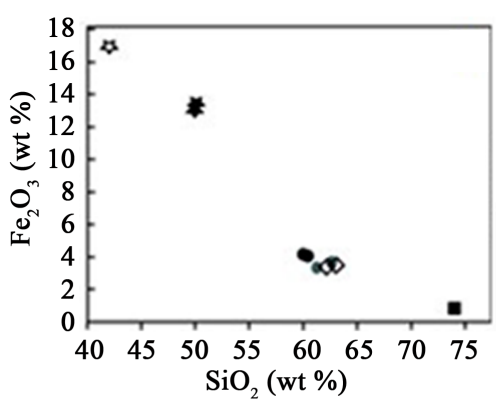

(a)

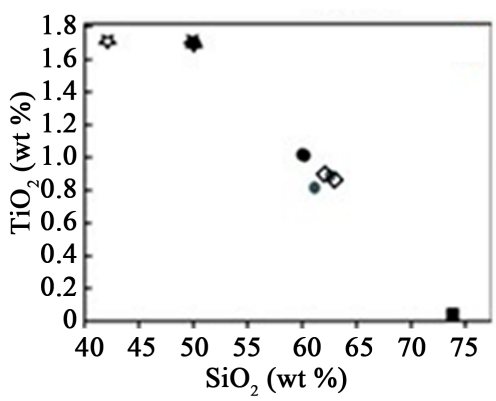

(c)

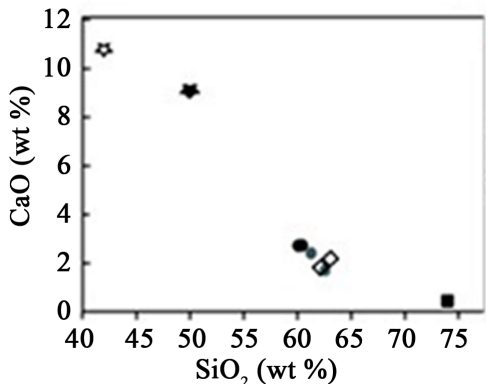

(e)

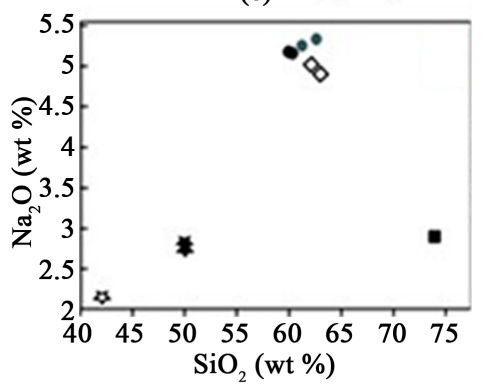

(g)

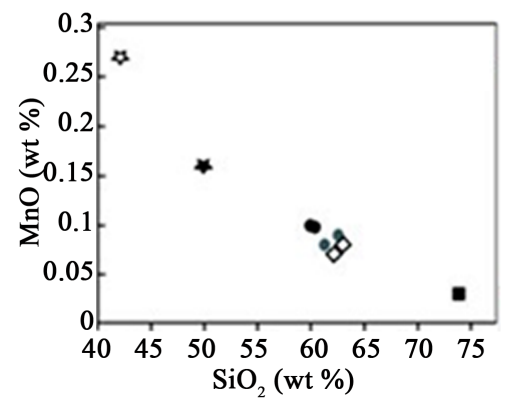

(i)

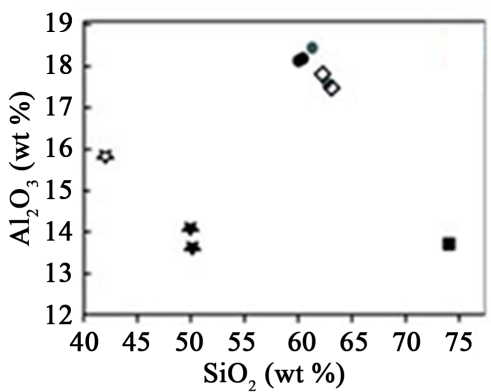

(b)

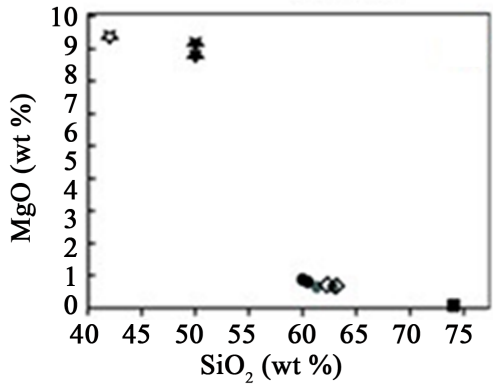

(d)

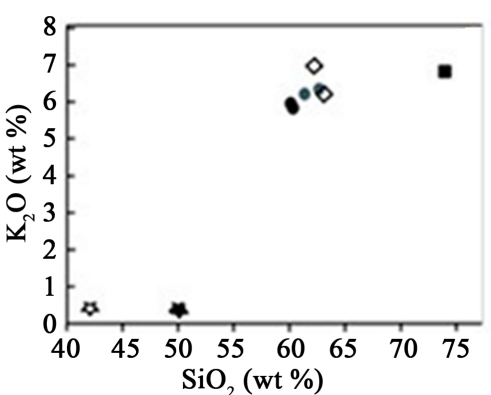

(f)

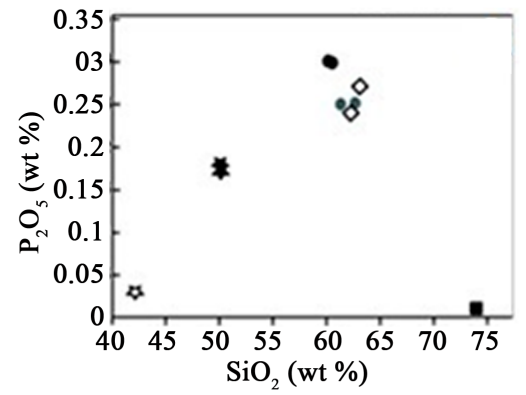

(h)
Grey syenite

Pink syenite

$\checkmark$ Whitish syenite
Contact granite Gabbro

$\sim$ Peridotgabbro

Figure 5. Major element (in oxide and wt\%) versus $\mathrm{Si}_{2} \mathrm{O}$ plots for Mindif syenites, contact granite, peridotgabbro and gabbro. 


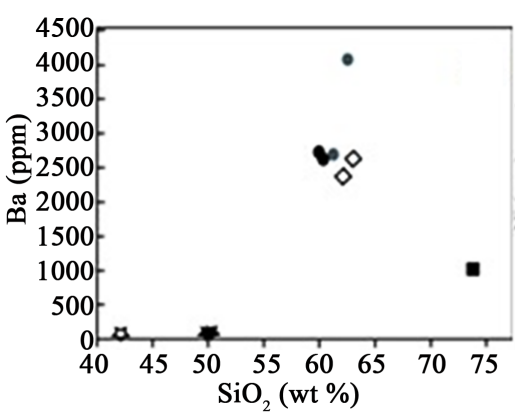

(a)

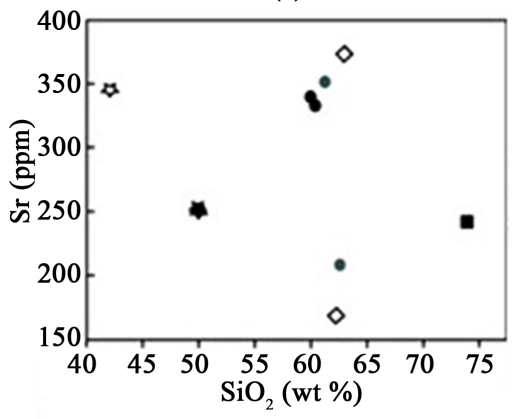

(c)

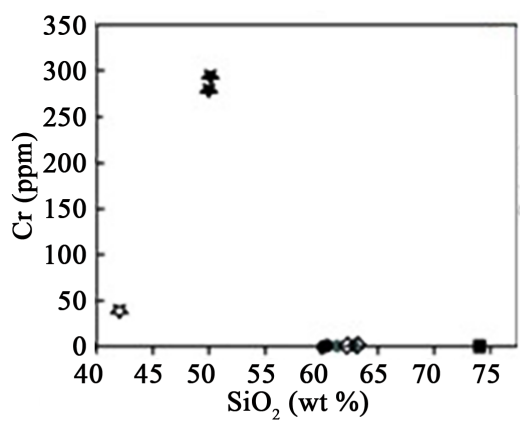

(e)

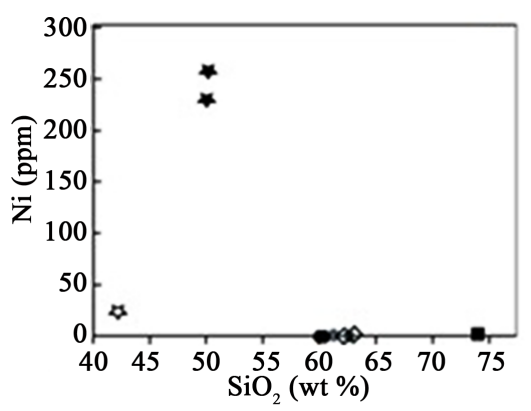

(b)

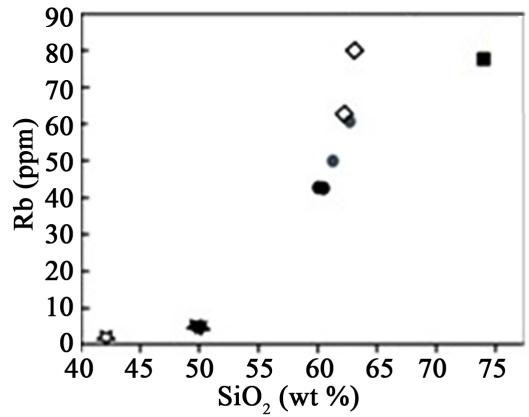

(d)

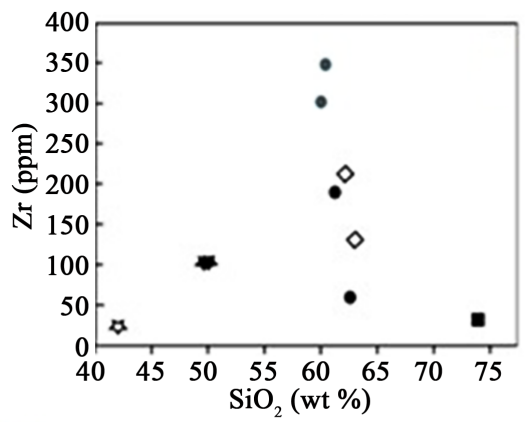

(f)

\section{Grey syenite \\ Pink syenite \\ Whitish syenite \\ D Contact granite

Figure 6. Selected trace element versus $\mathrm{SiO}_{2}$ plots for Mindif syenites, contact granite, peridotgabbro and gabbro.

enrichment (with $\left.(\mathrm{La} / \mathrm{Yb})_{\mathrm{N}}>10\right)$. Other element ratios are that of $\mathrm{Ba} / \mathrm{La}(118$ 79), $\mathrm{Ce} / \mathrm{Pb}(7$ - 5), Nb/La (0.65 - 0.5), and Th/La (0.07 - 0.01).

3) Spider diagram and REE patterns

The primitive mantle-normalized multi-element patterns (N-MORB) (normalization values after [40] spider diagram (Figure 7(a)) of Mindif syenites characterized by variable behavior of incompatible elements. This variation could reflect different history of crystallization and different source magma. Within the large-ion lithophile elements (LILE) suites, except for Sr (with flat or negative anomaly), $\mathrm{Rb}, \mathrm{Cs}, \mathrm{Ba}$, and $\mathrm{K}$ show very strong positive anomaly (high enrichment). For high-field-strength-element (HFSE), plots show strong to weak positive $\mathrm{Eu}$ and $\mathrm{Zr}$ anomaly; weak positive and negative to non-anomaly for $\mathrm{Y}$, 


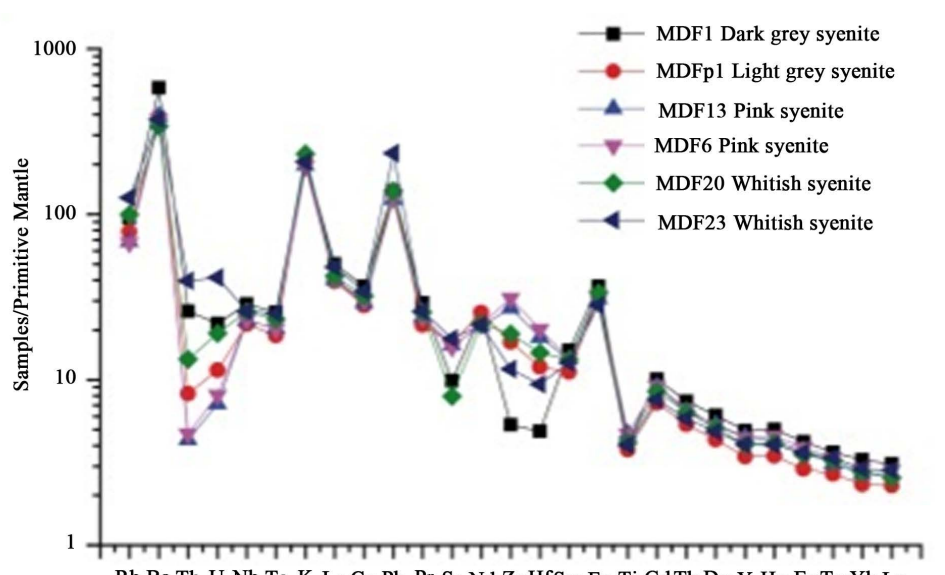

Rb Ba Th U Nb Ta K La Ce Pb Pr Sr Nd Zr HfSm Eu Ti Gd Tb Dy Y Ho Er TmYb Lu

(a)

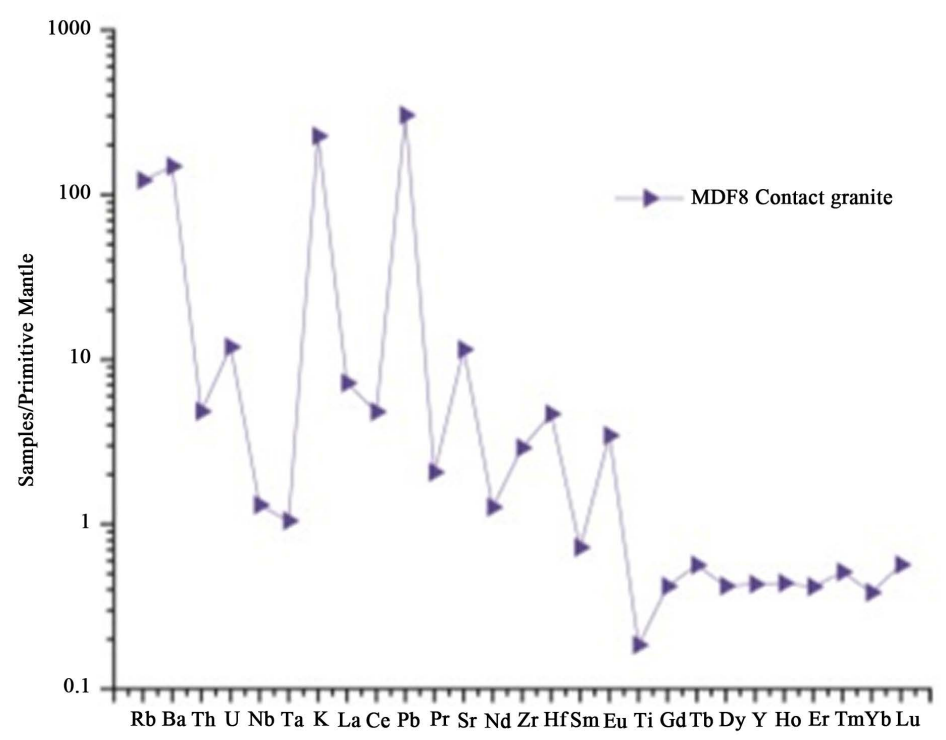

(b)

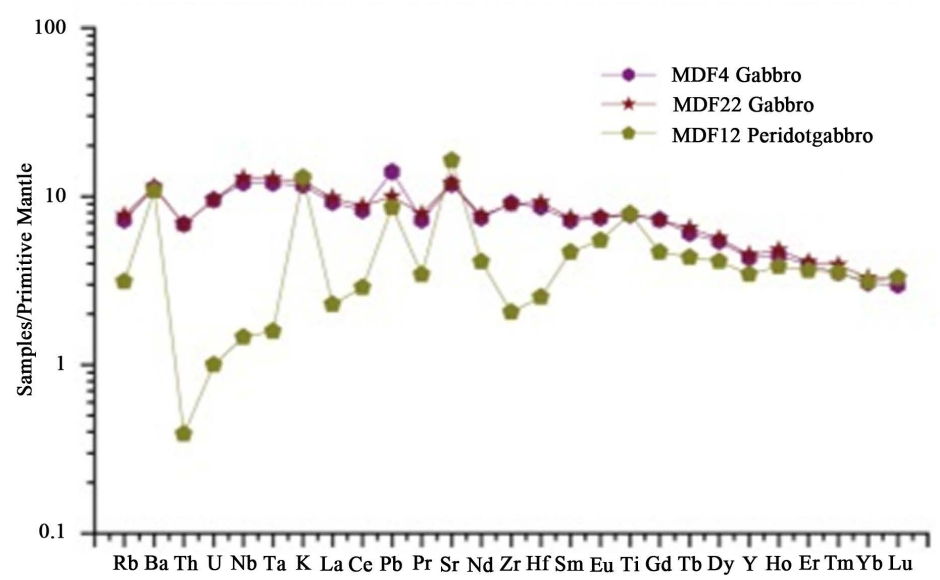

(c)

Figure 7. Primitive mantle-normalized multi-element patterns for felsic and mafic rocks in Mindif Complex ((a) syenites; (b) contact granite and (c) peridotgabbro and gabbro). The normalizing values and the values of OIB, N-MORB and E-MORB are from [40]. 
$\mathrm{Nb}, \mathrm{Sm}, \mathrm{U}, \mathrm{Nd}, \mathrm{Hf}$ and Th. Contact granite spider diagram (Figure 7(b)) with positive ( $\mathrm{Eu}, \mathrm{Ba}, \mathrm{K}, \mathrm{Hf}$, and $\mathrm{Zr}$ ) and negative $(\mathrm{Nb}, \mathrm{Sm}$ and $\mathrm{Nd}$ ) anomaly, shows clear difference with that of syenites. Selected compatible elements ( $\mathrm{Pb}$ and $\mathrm{Ti}$ ) for syenites and contact granite have different behavior, with pronounced positive $\mathrm{Pb}$ and pronounced $\mathrm{Ti}$ negative. The normalized REE patterns for syenites show overlapping of spider diagrams (Figure 8(a)) with slow decrease from La to $\mathrm{Sm}$, positive Eu anomalies, and slow decrease to almost flattening from $\mathrm{Gd}$ to $\mathrm{Lu}$. That of contact granite (Figure 8(b)), shows a fast decrease from La to Sm, a pronounced positive Eu anomaly, and an almost flat feature with weak positive $\mathrm{Tb}, \mathrm{Tm}$ and $\mathrm{Lu}$ anomalies.

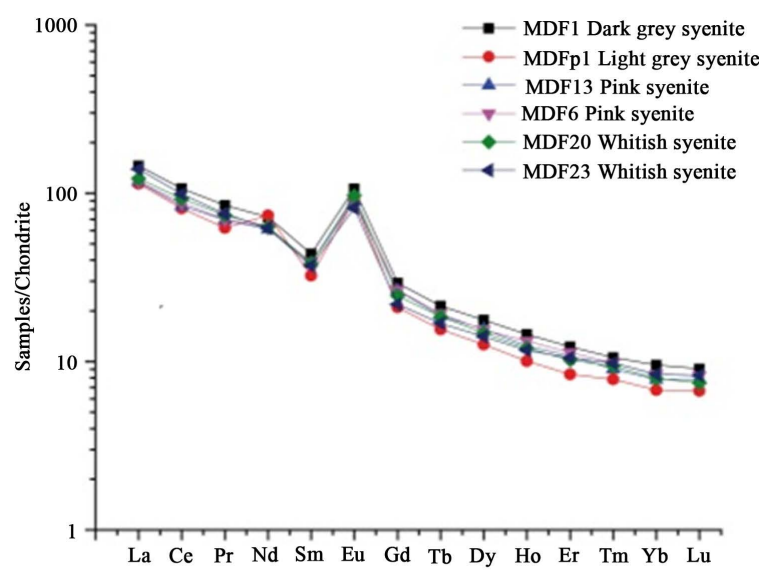

(a)

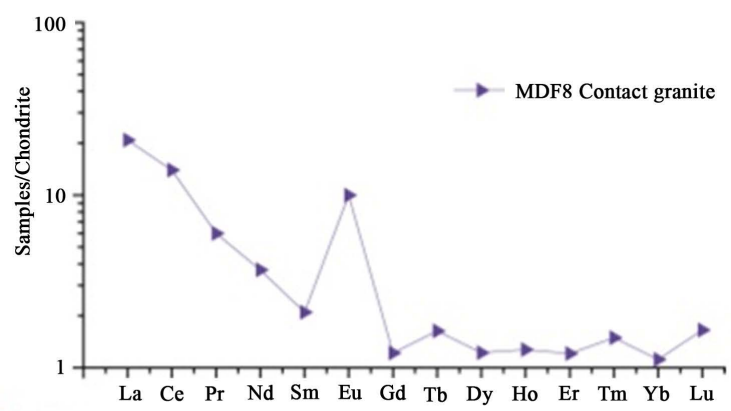

(b)

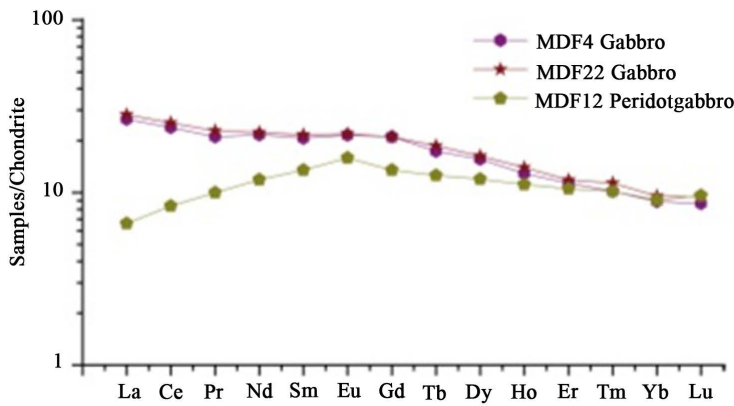

(c)

Figure 8. Rare earth element normalized patterns for felsic and mafic rocks in Mindif Complex ((a) syenites; (b) contact granite and (c) peridotgabbro and gabbro). The normalizing values and the values are from [40]. 


\subsubsection{Peridotgabbro and Gabbro}

1) Major and minor elements

Silica content is $42.08 \mathrm{wt} \%$ in peridotgabbro; and is up to $49.95 \mathrm{wt} \%$ in gabbro. The $\mathrm{Al}_{2} \mathrm{O}_{3}, \mathrm{Fe}_{2} \mathrm{O}_{3}, \mathrm{MgO}$ and $\mathrm{CaO}$ contents (in wt\%) are 15.83, 16.89, 9.29 and 10.79 in peridotgabbro, generally higher than those of gabbro. The $\mathrm{TiO}_{2}$, $\mathrm{MnO}, \mathrm{P}_{2} \mathrm{O}_{5}, \mathrm{Na}_{2} \mathrm{O}$ and $\mathrm{K}_{2} \mathrm{O}$ generally less than $3.0 \mathrm{wt} \%$ are relatively higher in gabbro than in peridotgrabbro. The $\mathrm{Mg \#}$ is 48.26 for peridotgabbro, and, up to 53.33 for gabbro. Excepting the slightly high $\mathrm{Fe}_{2} \mathrm{O}_{3}$ and $\mathrm{MgO}$, and low $\mathrm{SiO}_{2}$ contents in the study gabbro, contents of other oxides are much close to those in continental tholeiitic basalt and microgabbro found the haf-graben Mayo Ouo-Léré Basin (North Region of Cameroon: [41]). The distinction between the study peridotgrabbro and gabbro is clearly shown in Figure 2; as their plots fall in different positions. Peridotgabbro is alkaline whereas, gabbro is sub-alkaline in TAS diagram (Figure 2). The CIPW norms show the presence of nepheline in peridotgabbro, which is absent in gabbro (with normative hypersthene).

2) Trace and rare earth elements

Trace element contents in gabbro and peridotgabbro (Table 2), relatively distinguish: 1) high elements suite (101 - 345 ppm: $\mathrm{Sr}, \mathrm{Ni}, \mathrm{V}, \mathrm{Cr}, \mathrm{Cu}, \mathrm{Zn}$, and $\mathrm{Zr}$ ); 2) low element suite (15 - 80 ppm: $\mathrm{Ba}, \mathrm{Co}, \mathrm{Sc}, \mathrm{Y}$, and $\mathrm{Ga}$ ); and 3) very low (0.03 9.20 ppm: Nb, Li, Rb, Be, Hf, Sn, Ta, Th, Pb, Cs, and U). Incompatible element classification shows that within (LILE) and (HFSE), Sr (345 ppm in peridotgabbro and up to 252 in gabbro) and $\mathrm{Zr}$ ( $23 \mathrm{ppm}$ in peridotgabbro and up to 101 in gabbro), are the highest. Other distinctive features are the Sc ( $\leq 186 \mathrm{ppm}), \mathrm{V}$ ( $\leq 294 \mathrm{ppm}), \mathrm{Ni}(\leq 258 \mathrm{ppm}), \mathrm{Cu}(102 \mathrm{ppm})$ contents in gabbro, which are higher than those found in peridotgabbro (with highest $\mathrm{Zn}$ : $117 \mathrm{ppm}$ ). These trace element compositions are different to those in basalts at Kapsiki plateau studied by [25]. Trace element abundances in gabbro are much close to those in microgabbro and basalt cropping the Mayo Ouo-Léré Basin [41]. Calculated trace elements ratios in Table $2\left(\mathrm{Zr} / \mathrm{TiO}_{2}: 61-13\right.$; $\mathrm{Ba} / \mathrm{Nb}: 142$ - 9; Nb/U: 50 - 42; $\mathrm{Zr} / \mathrm{Hf}$ : 39 - 29; Sr/Y: 22 - 12; Nb/Ta: 18 - 16; Th/U: 3.0 - 1.5; Rb/Sr: 0.2 - 0.006; Y/Nb: 15.1 - 2.0) with low values generally being obtained in peridotgabbro. Binary plot diagrams of selected trace elements (Figure 6) mainly show closeness of gabbro clearly separated with peridotgabbro.

The value of total REE is 26.92 in peridotgabbro and up to $53.42 \mathrm{ppm}$ in gabbro. The highest REE content is that of $\mathrm{Ce}(\leq 15.5 \mathrm{ppm})$ and $\mathrm{Nd}(\leq 10.4 \mathrm{ppm})$ in gabbro. The content of these two elements and other REE are very low in peridotgabbro. The Eu anomaly in gabbro is close to 1.0, and 1.30 in peridotgabbro. The LREE/HREE $(3-1),(\mathrm{La} / \mathrm{Yb})_{\mathrm{N}}(3-0.6),(\mathrm{Ce} / \mathrm{Yb})_{\mathrm{N}}(2.6-0.8)$, and $(\mathrm{Tb} / \mathrm{Yb})_{\mathrm{N}}$ $(<2.0)$ ratios are significant, those of $\mathrm{Ba} / \mathrm{La}(49-11), \mathrm{Ce} / \mathrm{Pb}(22-8), \mathrm{La} / \mathrm{Nb}(0.7$

- 1.6) and $\mathrm{Th} / \mathrm{La}(\leq 0.09)$ are specific.

3) Spider diagram and REE patterns

N-MORB normalized (normalization values after [40]) spider diagram of Mindif gabbro and peridotgabbro (Figure $7(\mathrm{c})$ ) clearly shows difference between the two rock types. Within incompatible element suites, gabbro's dia- 
grams show weak positive $\mathrm{Sr}$ and $\mathrm{Ba}$ anomaly, weak negative $\mathrm{Rb}$, and mainly non-anomaly for other elements. Peridotgabbro's plot mainly shows strong positive $\mathrm{Ba}, \mathrm{K}$, and $\mathrm{Sr}$ (pronounced enrichment), weak positive Eu, strong negative $\mathrm{Rb}$, Th, La, and $\mathrm{Zr}$ anomaly (pronounced depletion), and mainly non-anomaly for other elements. Within selected compatible ( $\mathrm{Pb}$ and $\mathrm{Ti}$ ), peridotgabbro plot shows strong positive $\mathrm{Pb}$ and $\mathrm{Ti}$ anomaly, whereas, gabbro's plots show weak positive $\mathrm{Pb}$ and non $\mathrm{Ti}$ anomaly. The plotted normalized REE patterns in Figure $8(c)$ is almost flat for gabbro (with no Eu anomaly); but weakly increases from $\mathrm{La}$ to $\mathrm{Eu}$ and decreases from $\mathrm{Eu}$ to $\mathrm{Lu}$ for peridotgabbro.

\section{Discussions}

Field, petrographic and geochemical data are used to characterize each rock type cropping in the Mindif complex. The same data are used for pretrogenesis, tectonic evaluation and to assess their economic interest.

\subsection{Characterization and Classification}

Five rock types (syenitic bodies, contact granites, peridotgabbro, gabbro and amphibolite) present specific features that can be used to characterize and classify them.

\subsubsection{Syenitic Bodies and Granitic Contact Rock}

Syenitic rocks in Mindif complex are four types in color: pink, dark-grey, light-grey, and whitish. This difference is also texturally and compositionally visible; with pink syenite being fine to medium-grained, dyke-like and with no ferromagnesian mineral; dark-gray syenite (medium-grained, mesocratic and with few quartz); light-grey syenite (leucocratic, coarse grained to porphyritic with few ferromagnesian minerals) and whitish syenite (leucocratic coarse-grained to porphyritic, and with relatively higher proportion of ferromagnesian minerals). These variations are probably due to different crystallization environment and cooling history. Fine and medium-grained syenites are probably products of rapid to slow cooling of their magmas at shallow depth [9] [42]. Coarse-grained to porphyritic syenites crystallized from slow cooling of melts at deep seated environments [9] [42]. These differences are also geochemical (see plots in Figures 5-8) with some elements being highly concentrated in some syenites than in others, typifying high enrichments of specific elements in their source magmas. In TAS diagram (Figure 2), and with their CIPW norms, two groups are distinguished: (1) alkaline quartz-bearing syenites and (2) alkaline quartz-barren syenites (showing that they were cooled from alkaline magmas). The alkaline nature of the syenites is clear shown, as their plots fall in shoshonite series [43] (Figure 9(a)) and alkali field [44] (Figure 9(b)), and the $\mathrm{Na}_{2} \mathrm{O}+\mathrm{K}_{2} \mathrm{O}>11 \mathrm{wt} \%$ (compatible with value presented in [45] and alkaline plutons in [46]). Quartz alkaline syenites enclose the highest REE contents which coupled with their relatively low $\mathrm{Zr}$ value, differentiate them from other syenites. Excepting the contact granite which is peraluminous, all the syenites 


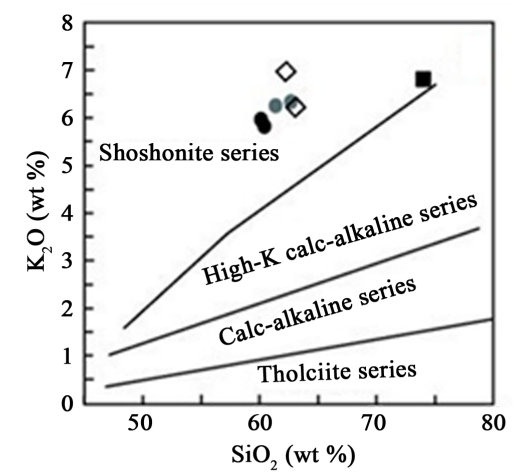

(a)

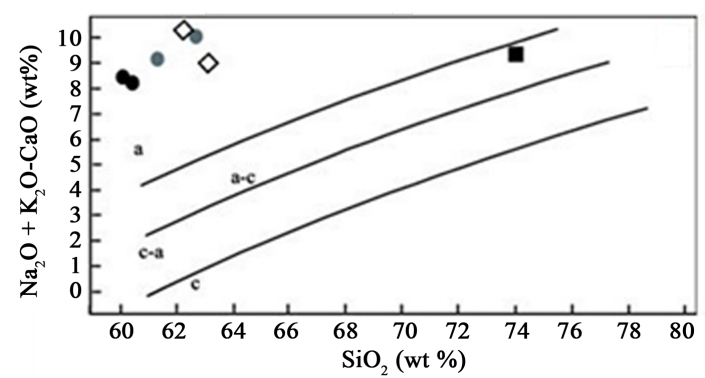

(b)

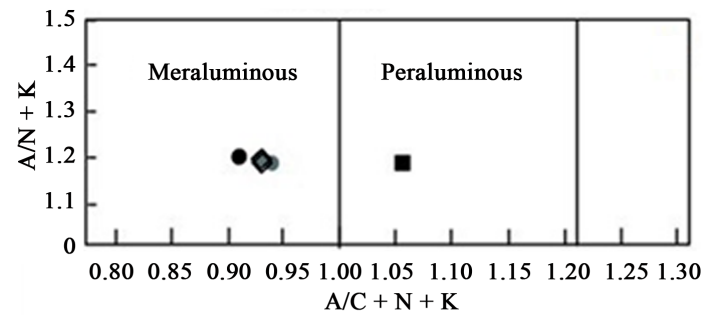

(c)

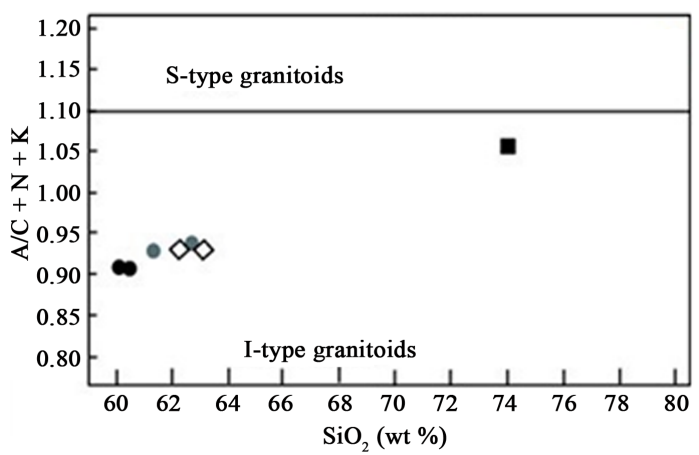

(d)

- Grey syenite

Pink syenite

$\checkmark$ Whitish syenite

Contact granite

Figure 9. Four binary diagrams classifying syenites and contact granite in Mindif Complex: (a) Plots in $\mathrm{SiO}_{2}$ versus $\mathrm{K}_{2} \mathrm{O}$ diagram of [43] binary diagrams classifying felsic and mafic rocks in Mindif Complex (high-K calc-alkaline, and Shoshonite affinities); (b) $\mathrm{Na}_{2} \mathrm{O}+\mathrm{K}_{2} \mathrm{O}-\mathrm{CaO}$ versus $\mathrm{SiO}_{2}$ diagram of [44] (a: alkalic, a-c: alkali-calcic, and c-a: calc-alkali groups); (c) molecular $\mathrm{Al}_{2} \mathrm{O}_{3} / \mathrm{Na}_{2} \mathrm{O}+\mathrm{K}_{2} \mathrm{O}$ versus $\mathrm{Al}_{2} \mathrm{O}_{3} / \mathrm{CaO}+\mathrm{Na}_{2} \mathrm{O}+\mathrm{K}_{2} \mathrm{O}$ plot in [47]; and (d) molecular $\mathrm{Al}_{2} \mathrm{O}_{3} / \mathrm{CaO}+\mathrm{Na}_{2} \mathrm{O}+\mathrm{K}_{2} \mathrm{O}$ versus $\mathrm{SiO}_{2}$ plots in [48]. 
are metaluminous, as show in Figure 9(c) [47]. Syenites and contact granite found in Mindif are I-type granitoids [48] (see Figure 9(d)) showing that their source magmas are from igneous origin. Petrographic differences coupled with alkalinity distinguish for four main groups of syenitic rocks: 1) hololeucocratic alkaline microsyenite; 2) mesocratic alkaline aplitic quartz-syenit; 3) leucocratic alkaline porphyritic quartz-biotite syenite; and 4) leucocratic alkaline porphyritic biotite-syenite.

\subsubsection{Peridotgabbro, Gabbro and Amphibolite}

Mafic igneous rocks in the Mindif complex include peridotgabbro (holomelamocratic and medium-grained), and gabbro (melanocratic and medium-grained). The medium-grained texture of peridotgabbro and gabbro shows that their source magmas probably cooled in shallow depth. These two rocks clearly show petrographic and geochemical differences (high olivine proportion in peridotgabbro and its relatively low $\mathrm{SiO}_{2}$ content $<43.0 \mathrm{wt} \%$; and very low olivine proportion and $\mathrm{SiO}_{2}>49.0 \mathrm{wt} \%$ in gabbro). This difference indicates that they are not from the same magma (peridotgabbro crystallized from silica depleted magma and gabbro, product of silica slightly enriched melt). Peridotgabbro could be originated from silica-undersaturated magma, as normative nepheline is determined. Gabbro with the absent of normative nepheline and quartz could be originated from a silica-saturated melt. The different between peridotgabbro and gabbro is shown in TAS diagram (Figure 2), as the first rock is plotted in alkaline field and the second, in sub-alkaline or tholeiitic. The tholeiitic nature of gabbro typifying that higher degrees of partial mantle melting were involved in the source magmas, as shown in [49] $\mathrm{Y} / \mathrm{Nb}$ versus $\mathrm{Zr} / \mathrm{Nb}$ of, $\mathrm{Zr} / \mathrm{Nb}$ versus $\mathrm{Zr} / \mathrm{Y}$, and $\mathrm{Zr}$ versus $\mathrm{Nb}$ diagrams (Figure 10 ). The other difference is the presence of normative hypersthene in gabbro and it absence in peridotgabbro. The relative high content alumina, iron oxide, $\mathrm{MgO}$ and $\mathrm{CaO}$ in peridotgabbro than in gabbro also differentiate this tow rocks. The high $\mathrm{Al}_{2} \mathrm{O}_{3}$ content in peridotgabbro is probably due to important plagioclase crystallization in this rock and could classify it as high-Al basaltic rock [50]; and, noted high $\mathrm{Fe}_{2} \mathrm{O}_{3}$ and $\mathrm{MgO}$ contents in this same rock can be justified by the presence of high olivine. The other difference is that of specific elements (e.g., $\mathrm{Cr}, \mathrm{Ni}, \mathrm{Cu}, \mathrm{Sr}$, $\mathrm{Zr}, \mathrm{Ba}$ and $\mathrm{REE}$ ) higher in gabbro than in peridotgabbro ( $\mathrm{V}, \mathrm{Sr}$, and Zn-enriched). For [51], continental alkaline basaltic rocks are often enriched in trace elements relative to oceanic counterparts. The trace elements abundances in peridotgabbro (the only studied alkaline basaltic rock) are globally less than those in continental basaltic rocks presented in [50] and [51]. They can therefore be classified as oceanic alkaline peridotgabbro. The Th $(<1.0 \mathrm{ppm})$ in gabbro is within the range limit in tholeiitic microgabbro and basalt found in Mayo Oulo-Léré Basin (North of Cameroon) which were classified as continental tholeiitic basaltic rocks [41]. The mafic rocks found within the Mindif complex can be named: 1) alkaline-nepheline peridotgabbro and 2) sub-alkaline olivine-hypersthene gabbro. Amphibolite-schist, melanocratic, fine-grained, 


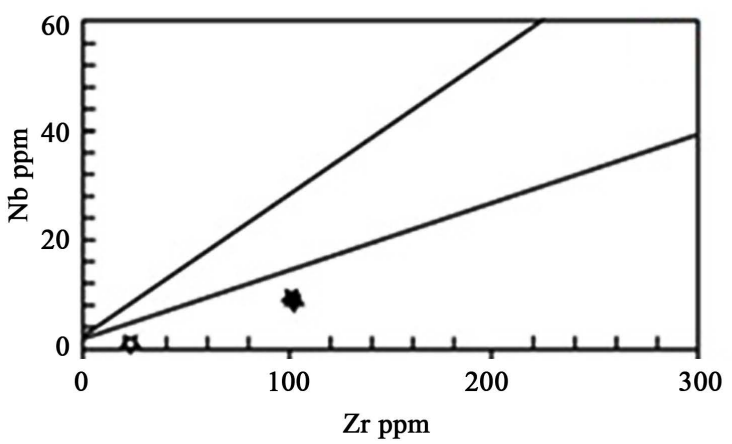

(c)

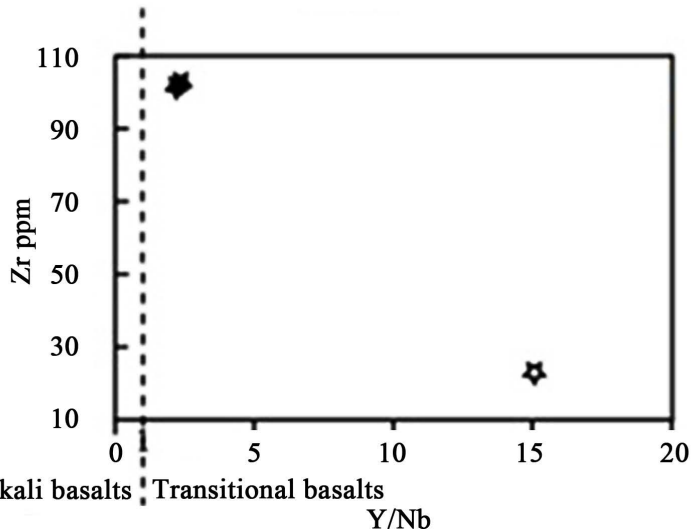

(b)

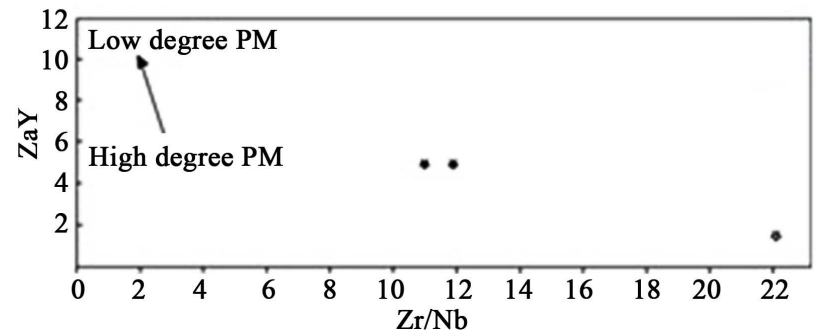

(c)

4 Gabbro

$\checkmark$ Peridot-gabbro

Figure 10. (a) $\mathrm{Nb}$ versus $\mathrm{Zr}$ plot diagram showing that gabbro and peridotgabbro represent two different magma types; (b) $\mathrm{Zr}$ versus $\mathrm{Y} / \mathrm{Nb}$ plot diagram distinguishing two basaltic groups. The boundary (by dashed) is from [49]; (c) $\mathrm{Zr} / \mathrm{Y}$ versus $\mathrm{Zr} / \mathrm{Nb}$ plot showing qualitative trend of compositions resulting from low versus high degrees of partial melting of the west and southern basaltic rocks (PM: primary mantle partial melting).

sheet-like, with pneumato-granoblastic texture relatively, is one of the oldest country rock in the study area as some fragments are reworked xenoliths in biotite porphyritic syenites.

\subsection{Pretrogenesis and Tectonic Evolution}

\subsubsection{Syenitic Bodies and Contact Granites}

Alkaline syenites found in Mindif complex with their variations, may have different crystallization history. Fracture filling materials represent discordant bo- 
dies probably cooled in shallow depth (less than $1 \mathrm{~km}$ ) whereas, stocks (mainly found in the locality), were cooled much deeper (probably at more than $1 \mathrm{~km}$ ) in the Earth Crust. The alkaline syenites were crystallized from silica-saturated melts (those without quartz) and silica-over-saturated melts (those with quartz). The two rocks identified to have cooled from silica-oversaturated melts (dark-grey and whitish syenite: quartz syenites) have color, textural and compositional differences proving that they never crystallized at the same depth and therefore, may not be from the same magma or represent different stage of a crystallizing magma. What is contrasting, is that these two rocks were located very far each other. In addition, dark-grey syenite has medium-grained texture, highest $\mathrm{Ba}, \mathrm{Nb}, \mathrm{Ta}$ and $\mathrm{Y}$ contents and lowest $\mathrm{Zr}$; which probably shows that it was crystallized at a much shallow depth (less than that of whitish syenite) from a Ba-Nb-Y-Ta-enriched magma. Dark-grey syenite locally underlay a highly weathered granitic cover, showing that its magma intruded the same granitic cover rock but at different depths and positions.

The granitic cover is locally cut by numerous and highly fractured pink microsyenitic dykes. The presence of a dyke in the cover rock, shows that it was affected by extension or the force of a rising magma diaper [42]. These dykes show that the granitic cover rock was locally affected by post emplacement cataclastic tectonics with composite magmatic injections into the opened gabs. The dykes are vertical and inclined with different strike and dip, which suggests a different extension direction during magma injections along the opened fractures. These dykes can be classified as multiple as they have closely the same composition, if [42] dyke classification is considered. From the obtained dip values, it is suggested that opening of the fractures involved lateral and ENE-WSW incline displacements with the maximum development of the dykes occurring where the fracture planes were mostly vertical. The fracture filled rocks are fine to medium-grained, alkali feldspar-rich, and have no hydrous minerals; suggesting crystallizations from dry residual alkaline melts during late stages syenitic magmatic differentiations in shallow depth. The presence of normative olivine and absence of quartz in the microsyenites shows cooling from silica-saturated magma (s). The presence elevated $\mathrm{TiO}_{2}$, in this rock; show an enrichment of titanium in their source magma, and the possible crystallization of ilmenite [51]. Ilmenite crystallization in the source magma of all the Mindif syenites can be confirmed as they all have slight high $\mathrm{TiO}_{2}$ content and normative ilmenite. The source magma of the syenitic dykes was also relatively Al-Zr-V-enriched but, silica and much alkali depleted; if compared with data of others syenites (Table 1 and Table 2). Contact granite at the edges of microsyenitic dykes and in contact with host rock, can be a product of magmatic mixture between the intrusive melt and magma from partial melting of the host rock. With $\mathrm{SiO}_{2}=74 \mathrm{wt} \%$, plotted in peraluminous field (Figure 9(c)) and lowest elementary contents, the contact granite cooled from silica-oversaturated and peraluminous melt with this melt being generally chemically depleted.

The presence of hydrous mineral (biotite) in light-grey and whitish syenite 
and their coarse-grained and porphyritic texture may show crystallization from less dry to high hydrous melts during magmatic differentiation in deep seated environments. The presence of sericite in alkali feldspar in those two rocks can reflect volatile increase magmatic phase [52]. These two syenites could be crystallized products from different magma phases, as these rocks have different color and CIPW mineralogy, plotted separately in TAS diagram and others discriminating diagrams (e.g., Figure 5 and Figure 6). The light-grey and whitish syenites locally encloses amphibolite xenoliths which are probably reworked materials sorted from the country rock forming the magmatic chamber by the cooling syenitic magmas when ascending. The structural, textural and compositional similarities between these mafic xenoliths and amphibolite schist outcropping in the east of the study area, show that they were sorted from this rock.

Alkaline magmatic rocks commonly formed in post-orogenic and intraplate tectonic settings; and can provide significant information magmatic processes within continental lithosphere [2] [10] [53]. Alkaline syenitic bodies can be product of crystallization of a mantle sourced magma or a magma of crustal origin [2] [53] [54]. Their geochemical features coupled with petrological data help to discriminate their crystallization conditions [2] [54]. The geochemical signatures precisely that of LILE and HFSE of syenite point in their evolutionary history [52] [55]. The relatively low content of most of the incompatible trace elements and $\mathrm{MgO}$ in Mindif syenites may simply reflect the dilution of the magma by large amounts of cumulate feldspar if base interpretation presented in [52]. For these same authors, negative Eu anomaly exhibited by syenitic rocks presumed to originate through feldspar fractionation during evolution from basaltic parent magmas; whereas positive Eu anomalies evidence that the generation of their magma involved significant feldspar accumulation. Feldspar accumulation and Eu-enrichment during the crystallization of syenite magma can be testified by presence of high proportion of alkali feldspar, low plagioclase and normative anorthite [56]. All Mindif syenites have positive Eu anormalies (Table 2, Figure 7(a) and Figure 8(a)), high microcline, low plagioclase and normative anorthite which implies that alkali feldspar accumulation was the main mechanism of Eu-enrichment in those syenites. Syenites crystallized from mantle source magma (example of that of Saima Alkaline Complex in NE China: [11]) has relatively high $\mathrm{MgO}$ (5.69 wt\%), $\mathrm{Ni}(92 \mathrm{ppm})$ and $\mathrm{Cr}(210 \mathrm{ppm})$ contents. The $\mathrm{MgO}$ $(<0.98 \mathrm{wt} \%), \mathrm{Ni}(<1.75 \mathrm{ppm})$ and $\mathrm{Co}(<2.0 \mathrm{ppm})$ are significantly lower than those in alkaline syenites crystallized from mantle source magma. They might be syenites crystallized in crustal source magmas, from partial melting of pre-existing igneous protoliths (plots I-field in Figure 9(d)).

\subsubsection{Peridotgabbro and Gabbro}

Peridotgabbro and gabbro are basaltic rocks crystallized from mantle source magma(s) in continental and oceanic settings. The study of a basaltic rock can elucidate the nature of the underlying upper mantle and even aspects of the composition of the lower mantle [27] [41] [42] [50] [51] [57] [58] [59]. The 
crystallization history of basaltic rocks can be understood by evaluating the behavior of less mobile elements (e.g., $\mathrm{Ti}$ and $\mathrm{Al}$ ), some incompatible elements ( $\mathrm{Zr}$, $\mathrm{Nb}, \mathrm{Th}, \mathrm{Y}, \mathrm{Ta}$, and REE) and certain compatible elements (Cr, Co, Ni) [41] [50] [51] [59] [60] [61]. Mindif gabbro and peridotgabbro are plagioclase-olivine bearing rocks with significant $\mathrm{Al}_{2} \mathrm{O}_{3}, \mathrm{CaO}, \mathrm{Fe}_{2} \mathrm{O}_{3}, \mathrm{MgO}$ and $\mathrm{TiO}_{2}$ content probably due to $\mathrm{Al}, \mathrm{Ca}, \mathrm{Fe}, \mathrm{Mg}$ and $\mathrm{Ti}$ enrichment in their source magma. The obtained values for those major and minor elements are generally less than those of mafic rocks in Mount Bamenda (CVL) [51] [57] and Mamfe Basin [50], and clearly differentiate them. Other distinctive feature is their very low trace and rare earth element contents. The $\mathrm{Sr}$ and Ba contents for examples, are very low compare to that of those in Mount Bamenda (mainly considered as high-Sr basaltic rocks: [51]) and in the Mamfe Basin (qualified as high-Ba basaltic rocks: [50]). Slightly Ti-enrichment (a less mobile element) in peridotgabbro could be due to ilmenite crystallization in its source magma. Zirconium, $\mathrm{Nb}, \mathrm{Ta}$, and $\mathrm{Hf}$ whose ratios $(\mathrm{Zr} / \mathrm{Hf}$ and $\mathrm{Nb} / \mathrm{Ta}$ ) are less changeable during crustal contamination and crystal differentiation processes show some similarities compare to that of primitive mantle are $\mathrm{Zr} / \mathrm{Hf}(36.27)$ and $\mathrm{Nb} / \mathrm{Ta}(17 \pm 2.0)$, respectively [62]. $\mathrm{The} \mathrm{Nb} / \mathrm{Ta}$ ratios for Mindif gabbroic rocks are close to that of the primitive mantle which is not the case with $\mathrm{Zr} / \mathrm{Hf}$ ratios (either less or greater than that of the primitive mantle). It can be suggested that mantle source magmas with crustal influences crystallized to give the Mindif gabbro and peridotgabbro. The mantle origin of their source magmas is shown in $\mathrm{Nb} / \mathrm{Th}$ versus $\mathrm{Zr} / \mathrm{Nb}$ and $\mathrm{Zr} / \mathrm{Y}$ versus $\mathrm{Nb} / \mathrm{Y}$ binary diagrams of [63] and [64] (Figure 11) in which gabbro are both influenced by deep depleted mantle (DPM) and oceanic plateau basalt (OPB) end-members (Figure 11(a)); and peridotgabbro influence only by DPM end-member (Figure 11(b)).

The use of $\mathrm{MgO}$ and $\mathrm{Mg}$ \# values of mafic rocks to interpret mantle event has been for rocks found along the Cameroon volcanic line [65]; an active N308E tectono-magmatic alignment, extending from Pagalu Island to Lake Chad [32]. Lavas from primitive upper mantle in equilibrium with olivine have the following features: $\mathrm{MgO}>6 \mathrm{wt} \%) ; \mathrm{Mg}$ \# (68 - 72); $\mathrm{Ni}(300-500 \mathrm{ppm}) ; \mathrm{Cr}(300-500$ ppm); Co (50 - $70 \mathrm{ppm})$; and La/Nb $(<0.8)$ [51] [66] [67]. The Ni ( $\leq 258 \mathrm{ppm})$, $\mathrm{Cr}(\leq 294 \mathrm{ppm}), \mathrm{Co}(\leq 57 \mathrm{ppm}), \mathrm{MgO}(\leq 9.10) ; \mathrm{Mg} \#(\leq 53.3)$ and $\mathrm{La} / \mathrm{Nb}(\leq 0.73)$ in gabbro (different to that of peridotgabbro) are mainly out of the range limit of values for in lavas from primitive upper mantle in equilibrium with olivine presented by [51] [66] and [67]. The Mg\# (48), $\mathrm{MgO}$ (9.29 wt\%), and $\mathrm{Ni}$ (24.1 ppm) for peridotgabbro are close to features in basaltic rocks cooled from more evolved mantle source magma, as presented in [50].

The LREE contents in both gabbro and peridotgabbro are largely greater than that of HREE. Alkaline peridotgabbro compare to most alkaline basaltic rocks along the Cameroon volcanic line, is depleted in incompatible elements and also has very low fractionation index $\left((\mathrm{La} / \mathrm{Yb})_{\mathrm{N}}: 0.7\right)$. Alkaline basaltic are often enriched in incompatible elements and have high fractionation index $(\mathrm{La} / \mathrm{Yb})_{\mathrm{N}}$ [51]. Heavy rare earth elements can be incorporated in garnet structure during 


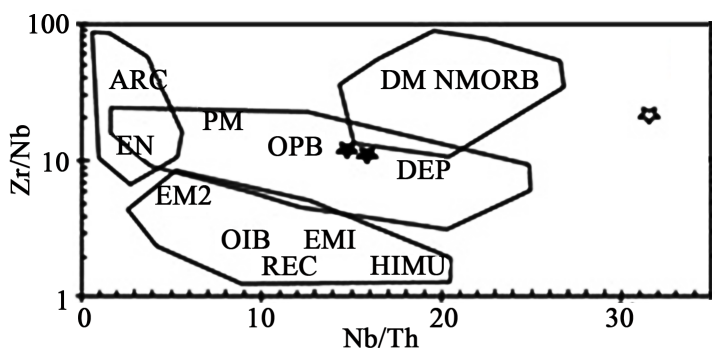

(a)

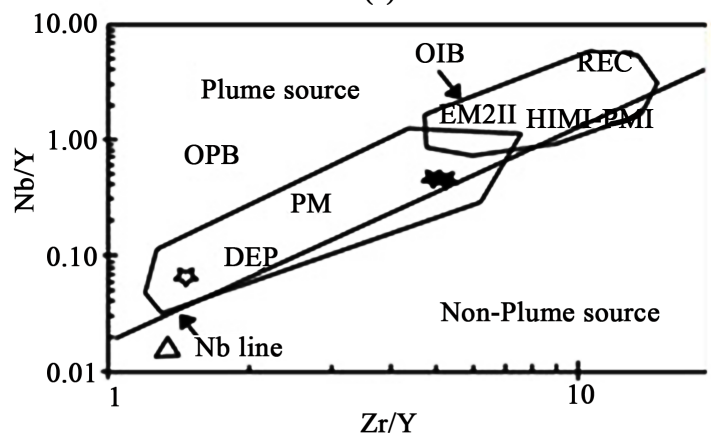

(b)

Gabbro
$\sim$ Peridot-gabbro

Figure 11. Gabbro and peridotgabbro plots relative to the mantle compositional components (filled star) and fields for basalts from various tectonic settings as defined by [63] and [64]. (a) $\mathrm{Nb} / \mathrm{Th}$ versus $\mathrm{Zr} / \mathrm{Nb}$ and (b) $\mathrm{Zr} / \mathrm{Y}$ versus $\mathrm{Nb} / \mathrm{Y}$ (PM: primitive mantle; DM: shallow depleted mantle; HIMU: high $\mathrm{mu}(\mathrm{U} / \mathrm{Pb})$ source; EM1 and EM2: enriched mantle sources; ARC: arc related basalts; N-MORB: normal ocean ridge basalt; OIB: oceanic island basalt; DEP: deep depleted mantle; EN: enriched component; REC: recycled component; OPB: oceanic plateau basalt.

basaltic magma crystallization (proven the existence of residual garnet in the source magma) [68]. Very high fractionation index corresponds to the depletion in HREE relative to LREE (otherwise, LREE enrichment) and indicate the presence of garnet as a residual phase in the sources of these rocks [51] [57] [69]. For [69] high $(\mathrm{Tb} / \mathrm{Yb})_{\mathrm{N}}$ in mafic volcanic rock also characterizes the presence of residual garnet in the mantle source. The very low $(\mathrm{Tb} / \mathrm{Yb})_{\mathrm{N}}$ ratios:1.3, coupled with the very low REE in peridotgabbro could just be due to limited presence of these elements in its source magma; as it would be difficult to certify the presence of residual garnet in the melt. This hypothesis is supported by their plots, very far to the garnet peridotite line and much close to transitional tholeiitic basalts (in $\mathrm{La} / \mathrm{Yb}$ versus $\mathrm{Dy} / \mathrm{Yb}$ discriminating diagram of [70] and [71]) (Figure $12(\mathrm{a})$ ). In $\mathrm{Sm} / \mathrm{Yb}$ versus $\mathrm{La} / \mathrm{Sm}$ binary diagram (Figure $12(\mathrm{~b})$ ), peridotgabbro is plotted a bit at the beginning of the Mid Ocean Ridge Basalt (MORB) line whereas, gabbro was plotted very far. This study tholeiitic gabbro is low-K, slightly LILE enriched and show pronounced $\mathrm{Nd}$ depletion. The features are close to those of Dabbah gabbros in Nubian Shield of Egypt [60] whose source magmas were suggested to be generated in subduction-related environments. The $\mathrm{Nb} / \mathrm{Th}$ ratios have been used in differentiating arc gabbros $(\mathrm{Nb} / \mathrm{Th}<7.5)$ from non-arc gabbros $(\mathrm{Nb} / \mathrm{Th}>8.5)[72]$. 


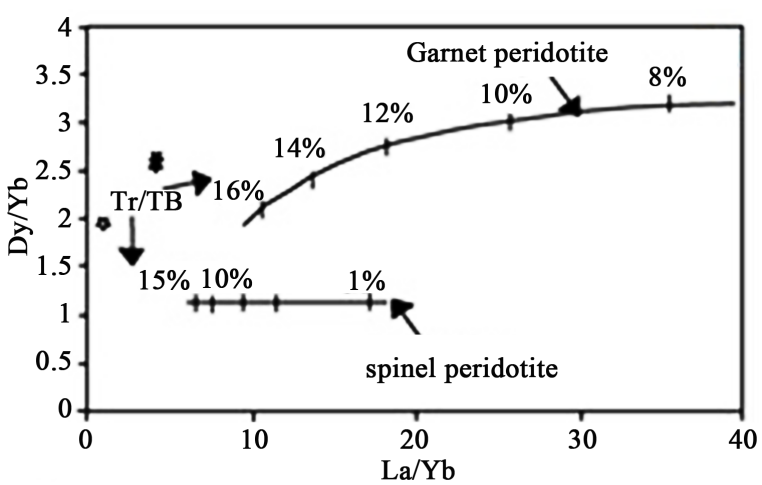

(a)

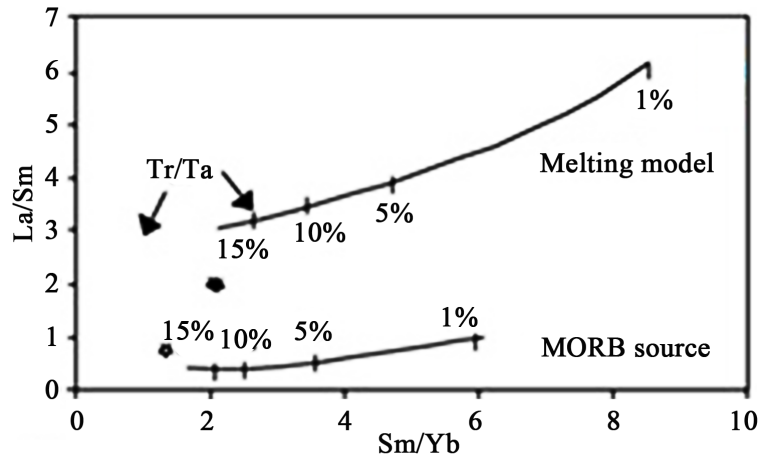

(b)

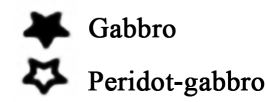

Figure 12. Gabbro and peridotgabbro plots in two source discriminating diagrams. (a) $\mathrm{La} / \mathrm{Yb}$ versus $\mathrm{Dy} / \mathrm{Yb}$ plot trend lines show degrees of partial mantle melting for garnet peridotite and spinel peridotite [70] [71]; (b) Sm/Yb versus La/Sm plot gives the melt plot trend lines are inverse batch partial mantle melting model and the depleted MORB source composition. TrTB (Transitional Tholeiitic Basalt) lie apart from the other plots and near higher degrees of melting generated from enriched source composition relative to N-MORB from [40].

$\mathrm{The} \mathrm{Nb} / \mathrm{Th}$ ratios (>14) for Mindif gabbroic rocks are within the limit of that of non-arc gabbros. These values are clearly different to those of Haoyaoerhudong arc gabbros (with their $\mathrm{Nb} / \mathrm{Th}$ ratios mostly ranging from 0.65 - 4.18) and suggested to have formed in a continental environment [61].

The Mindif tholeiitic gabbro is characterized by low $\mathrm{K}_{2} \mathrm{O}$, HFSE lower than $\mathrm{N}$-MORB values (Figure 9(c)), and REE patterns which are flat or slightly enriched (Figure 10(c)). These characteristics are similar those of Dabbah gabbros suggested to had formed from partial melting ultradepleted mantle source as a consequence of addition of sub-ducted slab-derived fluid to an overlying wedge mantle [60]. The medium-grained texture of the study gabbro opposite to that of Dabbah gabbros (coarse-grained) shows that Mindif gabbro represents the shallow equivalent of Dabbah gabbros. The trace and rare element abundances in Mindif gabbro and their plots (Figure 7(c)) are close to those of continental tholeiitic microgabbros and basalts found in Mayo Oulo-Léré Basin studied by [41]. The similarities may show the same crystallization history. For 
[41], the Mayo Oulo-Léré continental tholeiitic microgabbros and basalts were formed from high degrees of partial melting in an asthenospheric magma source, possibly related to lithospheric thinning which occurred between Santonian and Eocene. Peridotgabbro alkaline, with lower LREE and $(\mathrm{La} / \mathrm{Yb})_{\mathrm{N}}$, and slight marked positive Eu anomaly (different to that of Dabbah Tholeitic gabbros) could be originated from fractional crystallization with accumulation of plagioclase.

\subsection{Potential Uses of the Mindif Syenitic and Mafic Rocks}

Syenites are often used in ceramic and glass industries [73]. One of the key factor uses to identify good syenite in manufacturing glass and ceramic is its geochemical composition [12] [13] [19] [24]. The geochemical norms of a commercial beneficial grade syenitic product are $\mathrm{SiO}_{2}$ (60.04 wt\%), $\mathrm{Al}_{2} \mathrm{O}_{3}$ (23.03 wt\%), and $\mathrm{Fe}_{2} \mathrm{O}_{3}$ (0.08 wt\%) (Spectrum Canadian Nepheline Syenite, 2005) [24]. Excepting the $\mathrm{SiO}_{2}(\leq 60.08 \mathrm{wt} \%)$ in pink syenite, the $\mathrm{SiO}_{2}, \mathrm{Al}_{2} \mathrm{O}_{3}(17.48-18.43$ wt \%), and $\mathrm{Fe}_{2} \mathrm{O}_{3}$ (3.34 - $\left.4.16 \mathrm{wt} \%\right)$ contents are generally not compatible with required norms in grade A raw materials used to manufacture clear glass and ceramic items. The high iron and low aluminum in Mindif syenites negatively impact their uses in manufacturing clear glass and ceramic. However, some syenites (Bull's Run syenites in South Africa: [24] with $\mathrm{SiO}_{2}$ (50 - 60 wt\%), $\mathrm{Al}_{2} \mathrm{O}_{3}$ (15 - 17 wt\%) and $\mathrm{Fe}_{2} \mathrm{O}_{3}(4.9-5.7 \mathrm{wt} \%)$ were tested suitable for glass and ceramic industries. The alumina content required in glass ranges from $1.5 \%-2.0 \%$ in flat glass and up to $15 \%$ in some fiberglass [1]. Excepting the $\mathrm{SiO}_{2}$ slightly greater than that of Bull's Run syenites, the content of the other oxides in Mindif syenites is much closer to that of Bull's Run syenite. This geochemical similarity shows that the Mindif syenites can be used in glass and ceramic industries. Nevertheless, manufacturing tests are still needed to approve their use as raw material in these industries. For better uses in glass and ceramic industries, the iron content can be reduced to an average of $0.81 \mathrm{wt} \%$, and, that of alumina upgraded at above $20 \mathrm{wt} \%$ as was done red syenite in South Africa [24].

Syenites are mined and used as raw material for aluminum extraction in Russia [20], can host substantial amount of minable metals and/or gemstones [14] [22], or can weather to enrichment lateritic soil with aluminum in hot and humid tropical climate and plateau topography [17]. Mindif syenites with their significant alumina (up to $18.43 \mathrm{wt} \%$ ) can enrich a lateritic soil with aluminum if found on a plateau relief and in a humid tropical climatic zone. The climate in Mindif is hot tropical sahelian, and the relief is a plain cut by syenite's stocks forming inselbergs (not suitable for the concentration of lateritic bauxite). Transparent, colorless and very angular uncharacterized gemstones were sampled during this study in eluvial materials close to the contact between pink syenites and weathered granitic cover rock in the west of the study area. Although their origin not certain, their very angular texture and pegmatitic grain size (generally above $1 \mathrm{~cm}$ ) shows that they are proximal source(s) (probably from the underlying $\operatorname{rock}(\mathrm{s}))$. 
Gabbro and peridotgabbro found in Mindif Syenitic Complex are generally depleted in minable substance such as $\mathrm{Ni}, \mathrm{Co}, \mathrm{Zn}, \mathrm{V}$, and $\mathrm{Cr}$. The contents of these elements never exceed $500 \mathrm{ppm}$, lower than the contents in mineralized gabbroic rocks and $\mathrm{Ni}$-Co ultrabasic rocks (example of Lomié Ni-Co ultrabasic rocks in the East region of Cameroon studied by [74]). $\mathrm{The}_{2} \mathrm{Al}_{2} \mathrm{O}_{3}(15.82 \mathrm{wt} \%)$ in peridotgabbro is significant for weathering and formation lateritic bauxite, as this value greater than those found in the parent rock of $\left(\mathrm{Al}_{2} \mathrm{O}_{3}: 15.5 \mathrm{wt} \%\right.$ in basalt) Bangam and $\left(\mathrm{Al}_{2} \mathrm{O}_{3}: 15.6 \mathrm{wt} \%\right.$ in basalt) Fongo-Tongo bauxites in the West Region of Cameroon [75].

\section{Conclusions}

Mindif Complex is composed of syenites (pink, dark-grey, light-grey, and whitish), contact-granite, gabbro, peridotgabbro and amphibolite schist with different characteristics and crystallization history.

Pink syenites are dyke-like, fine to medium-grained cooled in shallow depth from much Al-rich and dry residual alkaline-silica-saturated melts during fractured tectonic-magmatic evens. Medium to coarse-grained-peraluminous granite found at the contact between pink syenites and granitic host, is probably a product of magmatic mixing between the intrusive syenitic melt and melt from partial fusion of the granite host rock.

Dark-grey syenite is a quartz-bearing medium-grained rock cooled in shallow depth from more Al-Ba rich-hydrous residual alkaline silica-oversaturated melt during fractional magmatism. Light-grey and whitish syenites are coarse to porphyritic stocks cooled deep-seated from alkaline silica-saturated and silica-oversaturated hydrous rich melts with important feldspar accumulations.

Peridotgabbro is a medium-grained, ultrabasic and alkaline rock, crystallized in shallow depth from more evolved mantle source silica-undersaturated magma with plagioclase accumulation. Gabbro is a medium-grained, crystallized in shallow depth from silica-saturated magma originated from partial melting ultradepleted mantle source in subduction environment. Amphibolite schist is a medium-grained, sheet-like, and pneumato-granoblastic metamorphic basement rock cut and reworked by biotite syenitic stocks.

Mindif syenites and peridotgabbro represent high- $\mathrm{Al}_{2} \mathrm{O}_{3}$ rocks capable to enrich lateritic soil with aluminum under a humid tropical climate on a plateau topography. These syenites can be used in some cases in glassy and ceramic industries after treatment.

\section{Acknowledgements}

The authors extend their gratitude to I.R.G.M for the petrographic laboratory facility. Thanks to the personnel at Australia Laboratory Services and at Sample Solution Co. Ltd. (Wuhan, China) for the geochemical analyses.

\section{Conflicts of Interest}

The authors declare no conflicts of interest regarding the publication of this paper. 


\section{References}

[1] Everard, L.J. (1998) An Assessment of the Resource Potential for Nepheline Syenite at Cygnet and Elsewhere in Tasmania. Tasmanian Geological Survey Record 1996/13, 1-16.

[2] Yang, J.H., Chung, S.L., Wilde, S.A., Wu, F.Y., Chu, M.F., Lo, C.H. and Fan, H.R. (2005) Petrogenesis of Post-Orogenic Syenites in the Sulu Orogenic Belt, East China: Geochronological, Geochemical and Nd-Sr Isotopic Evidence. Chemical Geology, 214, 99-125. https://doi.org/10.1016/j.chemgeo.2004.08.053

[3] Mukhopadhyay, S., Ray, J., Balaram, V., Krishna, A.K., Ghosh, B. and Mukhopadhyay, S. (2011) Geochemistry and Petrogenesis of Syenites and Associated Rocks of the Elagiri Complex, Southern Granulite Terrane, India. Journal of Asian Earth Sciences, 42, 1256-1270. https://doi.org/10.1016/j.jseaes.2011.07.011

[4] Litvinovsky, B.A., Jahn, B.M. and Eyal, M. (2015) Mantle-Derived Sources of Syenites from the A-Type Igneous Suites-New Approach to the Provenance of Alkaline Silicic Magmas. Lithos, 232, 242-265.

https://doi.org/10.1016/j.lithos.2015.06.008

[5] Anderson, I.C., Frost, C.D. and Frost, B.R. (2003) Petrogenesis of Red Mountain Pluton, Laramie Anorthosite Complex Wyoming: Implications for the Origin of A-Type Granite. Precambrian Research, 124, 243-267.

https://doi.org/10.1016/S0301-9268(03)00088-3

[6] Dawaï, D., Bouchez, J.L., Paquette, J.L. and Tchamini, R. (2013) The Pan-African Quartz-Syenite of Guider (North Cameroon): Magnetic Fabric and U-Pb Dating of Late-Orogenic Emplacement. Precambrian Research, 236, 132-144. https://doi.org/10.1016/j.precamres.2013.07.008

[7] Halama, R., Vennemann, T., Siebel, W. and Markl, G. (2005) The Gronnedal-Ika Carbonatite-Syenite Complex, South Greenland: Carbonatite Formation Liquid Immiscibilty. Journal of Petrology, 46, 191-217. https://doi.org/10.1093/petrology/egh069

[8] Nude, P.M., Shervais, J.W., Attoh, K., Scott, K., Vetter, S.K. and Barton, C. (2009) Petrology and Geochemistry of Nepheline Syenite and Related Carbonate-Rich Rocks in the Pan-African Dahomeyide Orogen, Southeastern Ghana, West Africa. Journal of African Earth Sciences, 55, 147-157. https://doi.org/10.1016/j.jafrearsci.2009.03.010

[9] Gill, R. (2010) Igneous Rocks and Processes: A Practical Guide. John Wiley \& Sons Ltd., Hoboken.

[10] Mukhopadhyay, S., Ray, J., Chattopadhyay, B., Sengupta, S., Ghosh, B. and Mukhopadhyay, S. (2011) Significance of Mineral Chemistry of Syenites and Associated Rocks of the Elagiri Complex, Southern Granulite Terrane of the Indian Shield. Journal of the Geological Society of India, 77, 113-129. https://doi.org/10.1007/s12594-011-0015-6

[11] Zhu, Y.S., Yang, J.H., Sun, J.F., Zhang, J.H. and Wu, F.Y. (2015) Petrogenesis of Coeval Silica-Saturated and Silica-Undersaturated Alkaline Rocks: Mineralogical and Geochemical Evidence from the Saima Alkaline Complex, NE China. Journal of Asian Earth Sciences, 117, 184-207. https://doi.org/10.1016/j.jseaes.2015.12.014

[12] Xu, C., Zhang, H., Huang, Z. and Guan, T. (2004) Genesis of Carbonatite-Syenite Complex and REE Deposits at Maoniuping, Sichuan Province, China: Evidence from $\mathrm{Pb}$ Isotope Geochemistry. Geochemical Journal, 38, 67-76.

[13] Sorensen, H., Bailey, J.C. and Rose-Hansen, J. (2011) The Emplacement and Crystallization of the U-Th-REE-Rich Agpaitic and Hyperagpaitic Lujavrites at Kvanef- 
jeld, Illimaussaq Alkaline Complex, South Greenland. Bulletin of the Geological Society of Denmark, 59, 69-92.

[14] Zhang, J., Lin, S., Linnen, R. and Martin, R. (2014) Structural Stetting of the Young-Davidson Syenite-Hosted Gold Deposit in the Western Cadillac-Larder Lake Deformation Zone, Abitibi Greenstone Belt, Superior Province, Ontario. Precambrian Research, 248, 39-59. https://doi.org/10.1016/j.precamres.2014.04.007

[15] Sorokina, E.S., Karampelas, S., Nishanbaev, P.T. and Sergev, N. (2017) Sapphire Megacrysts in Syenite Pegmatites from the Ilmen Mountains, South Urals, Russia: New Mineralogical Data. The Canadian Mineralogist, 55, 823-843. https://doi.org/10.3749/canmin.1700016

[16] Côté, G., Moukshi, A., Constantin, M. and David, J. (2018) Geochemical Characterization, Geochronology and Geodynamic Implication of Grenville Rare Earth Bearing Syenites, Haut-Saint-Maurice, QC, Canada. Minerals, 8, 336. https://doi.org/10.3390/min8080336

[17] Boulangé, B. and Colin, F. (1994) Rare Earth Element Mobility during Conversion of Nepheline Syenite into Lateritic Bauxite at Passa Quatro, Minais Gerais, Brazil. Applied Geochemistry, 9, 701-711. https://doi.org/10.1016/0883-2927(94)90029-9

[18] Uher, P., Gregáňová, G. and Szakáll, S. (2006) Sapphire-Host Syenite Xenolith from Cortva, Cerova Mountains, Slovakia. Acta Mineralogica-Petrographica, Abstract Series 5, Szeged.

[19] Abouzeid, A.-Z.M. and Negm, A.-T.A. (2014) Characterization and Beneficiation of an Egyptian Nepheline Syenite Ore. International Journal of Mineralogy, 2014, Article ID: 128246. https://doi.org/10.1155/2014/128246

[20] Panov, A., Vinogradov, S. and Engalychev, S. (2017) Evolutional Development of Alkaline Aluminosilicates Processing Technology. In: Ratvik, A., Eds., Light Metals 2017. The Minerals, Metals \& Materials Series, Springer, Cham, 9-16. https://doi.org/10.1007/978-3-319-51541-0_2

[21] Petrella, L., Williams-Jones, A.E., Goutier, J. and Walsh, J. (2014) The Nature and Origin of the Rare Earth Element Mineralization in Misery Syenitic Intrusion, Northern Quebec, Canada. Economic Geology, 109, 1643-1666. https://doi.org/10.2113/econgeo.109.6.1643

[22] Bigot, L. and Jébrak, M. (2015) Gold Mineralization at the Syenite-Hosted Beattie Gold Deposit, Duparquet, Neoarchean Abitibi Belt, Canada. Economic Geology, 110, 315-335. https://doi.org/10.2113/econgeo.110.2.315

[23] Bøgvad, R. (1950) Nepheline Syenite and Iron Ore Deposits in Greenland. Archives, 3, 86-94. https://doi.org/10.14430/arctic3956

[24] Pantshi, B. and Theart, H.F.J. (2008) The Red Syenite of the Pilanesberg Complex: A Potential Raw Material Source for the South African Ceramics and Glass Industry. South African Journal of Geology, 111, 27-38. https://doi.org/10.2113/gssajg.111.1.27

[25] Dumort, J.C. (1968) Carte géologique de reconnaissance du Cameroun à l'échelle du 1/500000 feuille Douala-Ouest, avec notice explicative (Imprimerie Nationale, Cameroun). Impr. Nationale, Paris.

[26] Owona, S. (2008) Archean-Eburnean and Pan-African Features and Relationships in Their Junction Zone in the South of Yaoundé (Cameroon). PhD Thesis, University of Douala, Cameroon.

[27] Ngounouno, I., Déruelle, B. and Demaiffe, D. (2000) Petrology of the Bimodal Cenozoic Volcanism of the Kapsiki Plateau (Northernmost Cameroon, Central Afri- 
ca). Journal of Volcanology and Geothermal Research, 102, 21-44. https://doi.org/10.1016/S0377-0273(00)00180-3

[28] Adjia, H.Z., Villiéras, F., Kamga, R. and Thomas, F. (2013) Mineralogy and Physico-Chemical Properties of Alluvial Clays from Far-North Region of Cameroon: A Tool for an Environmental Problem. International Journal of Water Resources and Environmental Engineering, 5, 54-66.

[29] Tsozué, D., Nzeugang, A.N. and Azinwi, P.T. (2017) Genesis and Classification of Soils Developed on Gabbro in the High Reliefs of Maroua Region, North Cameroon. Eurasian Journal of Soil Science, 6, 168-177. https://doi.org/10.18393/ejss.286631

[30] Tsozué, D., Nzeugang, A.N., Mache, J.R., Lowel, S. and Fagel, N. (2017) Mineralogical, Physic-Chemical and Technological Characterization of Clays from Maroua (Far-North, Cameroun) for Use Ceramic Bricks Production. Journal of Building Engineering, 11, 17-24. https://doi.org/10.1016/j.jobe.2017.03.008

[31] Déruelle, B., Ngounouno, I. and Bardintzeff, M.J. (2001) Wherlites et pyroxénites en nodules dans les basaltes du Mt. Cameroun: Évidence d'un métasomatisme mantellique. Journal de la Société de Géoscience d Afrique, 1, 90-91.

[32] Déruelle, B., Ngounouno, I. and Demaiffe, D. (2007) The "Cameroon Hot Line" (CHL): A Unique Example of Active Alkaline Intraplate Structure in Both Oceanic and Continental Lithospheres. Comptes Rendus Geoscience, 339, 589-600. https://doi.org/10.1016/j.crte.2007.07.007

[33] Toteu, S.F., Michard, A., Bertrand, J.M. and Rocci, G. (1987) U-Pb Dating of Precambrian Rocks from Northern Cameroon, Orogenic Evolution and Chronology of Pan-African Belt of Central Africa. Precambrian Research, 37, 71-87. https://doi.org/10.1016/0301-9268(87)90040-4

[34] Dumort, C.J. and Péronne, Y. (1966) Carte Géologique de Reconnaissance à l'échelle du 1/500000. République Fédérale du Cameroun, feuille Maroua (BRGM, Cameroun).

[35] Déruelle, B., Moreau, C., Nkoumbou, C., Kambou, R., Lissom, J., Njonfang, E., Ghogomu, T.R. and Nono, A. (1991) The Cameroon Line: A Review. In: Kampunzu, B.A. and Lubala, T.R., Eds., Magmatism in Extensional Structural Settings. The Phanerozoic African Plate, Berlin, Springer, 274-327. https://doi.org/10.1007/978-3-642-73966-8_12

[36] Gouthier, J., Nougier, J. and Nougier, D. (1974) Contribution à l'étude volcanologique du Cameroun (Ligne du Cameroun Adamaoua). Annale de la Faculté des Sciences, Université de Yaoundé, Cameroun, 17, 3-48.

[37] Vincent, M.P. and Armstrong, L.R. (1973) Volcanism of the Kapsiki Plateau (North Cameroon) and the Underlying Sedimentary Formations. Colloquium on African Geology, Florence, abstract, unpublished.

[38] Wang, L.X., Ma, C.Q., Zhang, C., Zhu, Y.X. and Marks, M.A.W. (2018) Halogen Geochemistry of I- and A-Type Granites from Jiuhuashan Region (South China): Insights into the Elevated Fluorine in A-Type Granite. Chemical Geology, 478, 164-182. https://doi.org/10.1016/j.chemgeo.2017.09.033

[39] Cox, G.K., Bell, D.J. and Pankhurst, J.R. (1979) The Interpretation of Igneous Rocks. George Allen \& Unwin, London.

[40] Sun, S. and McDonough, F.W. (1989) Chemical and Isotopic Systematics of Oceanic Basalts, Implications for Mantle Compositions and Processes. In: Saunders, A.D. and Norry, M.J., Eds., Magmatism in the Ocean Basins, Vol. 42, Geological Society Special Publication, 313-345. https://doi.org/10.1144/GSL.SP.1989.042.01.19 
[41] Ngounouno, I., Déruelle, B., Guiraud, R. and Vicat, J.P. (2001) Magmatismes tholéiitique et alcalin des demi-grabens crétacés de Mayo Oulo-Léré et de Babouri-Figuil (Nord du Cameroun-Sud du Tchad) en domaine d'extension continentale. Comptes Rendus de P Académie des Sciences, 333, 201-207. https://doi.org/10.1016/S1251-8050(01)01626-3

[42] Winter, J.D. (2014) Principles of Igneous and Metamorphic Petrology: Pearson New International Edition. Pearson Education Limited, Harlow, UK.

[43] Peccerillo, A. and Taylor, R.S. (1976) Geochemistry of Eocene Calc-Alkaline Volcanic Rocks from the Kastamonu Area, Northern Turkey. Contributions to Mineralogy and Petrology, 58, 63-81. https://doi.org/10.1007/BF00384745

[44] Frost, R.B., Barnes, G.C., Collins, J.W., Arculus, J.R., Ellis, J.D. and Frost, D.C. (2001) A Geochemical Classification for Granitic Rocks. Journal of Petrology, 42, 2033-2048. https://doi.org/10.1093/petrology/42.11.2033

[45] Le Maitre, W.R., Streckeisen, A., Zanettin, B., Le Bas, J.M., Bonin, B., Bateman, P., Bellieni, G., Dudek, A., Efremova, S., Keller, J., Lameyre, J., Sabine, A.P., Schimd, R., Sorensen, H. and Woolley, A.R. (2002) Igneous Rocks: A Classification and Glossary of Terms. 2nd Edition, Cambridge University Press, Cambridge. https://doi.org/10.1017/CBO9780511535581

[46] Njonfang, E. and Moreau, C. (1996) The Mineralogy and Geochemistry of a Subvolcanic Alkaline Complex from the Cameroon Line, the Nda Ali Massif, South-West Cameroon. Journal of African Earth Sciences, 22, 113-132. https://doi.org/10.1016/0899-5362(96)00126-1

[47] Maniar, D.P. and Piccoli, M.P (1989) Tectonic Discrimination of Granitoids. Geological Society of America Bulletin, 101, 635-643.

[48] White, R.J.A. and Chappell, W.B. (1977) Ultrametamorphism and Granitoid Genesis. Tectonophysics, 43, 7-22. https://doi.org/10.1016/0040-1951(77)90003-8

[49] Pearce, A. and Cann, R.J. (1973) Tectonic Setting of Basic Volcanic Rocks Determined Using Trace Element Analyses. Earth and Planetary Science Letters, 19, 290-300. https://doi.org/10.1016/0012-821X(73)90129-5

[50] Kanouo, N.S., Yongue, R.F., Ghogomun, R.T., Njonfang, E., Yomeun, S.B. and Basua, A.A. (2017) Petro-Geochemistry, Genesis and Economic Aspects of Mafic Volcanic Rocks in the West and Southern Part of The Mamfe Basin (SW Cameroon, Central Africa). Journal of Geology \& Geophysics, 6, 298. https://doi.org/10.4172/2381-8719.1000298

[51] Kamgang, P., Chazot, G., Njonfang, E., Ngongang, N.B.T. and Tchoua, F.M. (2013) Mantle Sources and Magma Evolution beneath the Cameroon Volcanic Line: Geochemistry of Mafic Rocks from the Bamenda Mountains (NW Cameroon). Gondwana Research, 24, 727-741. https://doi.org/10.1016/j.gr.2012.11.009

[52] Walkins, R.T. and Le Roex, A.P. (1991) Petrology and Structure of Syenite Intrusions of the Okenyenya Igneous Complex. Communications of the Geological Survey of Namibia, 7, 59-75.

[53] Rosa, P. and Ruberti, E. (2018) Nepheline Syenites to Syenites and Granitic Rocks of the Itatiaia Alkaline Massif, Southeastern Brazil: New Geological Insights into a Migration Ring Complex. Brazilian Journal of Geology, 48, 347-372. https://doi.org/10.1590/2317-4889201820170092

[54] Lubala, R.T., Frick, C., Rogers, J.H. and Walraven, F. (1994) Petrogenesis of Syenites and Granites of the Schiel Alkaline Complex Northern Transvaal, South Africa. The Journal of Geology, 102, 307-316. https://doi.org/10.1086/629673

[55] Heilimo, E., Mikkola, P., Huhma, H. and Halla, J. (2017) Alkaline Rich Quartz Sye- 
nite Intrusions of the Western Kariela Subprovince. Geological Society, London, Special Publications, 449, 61-88. https://doi.org/10.1144/SP449.4

[56] Schnetzler, C.C. and Philpotts, A.J. (1970) Partition Coefficient of Rare Earth Elements between Igneous Matrix Material and Rock-Forming Mineral Phenocrysts-II. Geochimica et Cosmochimica Acta, 34, 331-340. https://doi.org/10.1016/0016-7037(70)90110-9

[57] Kamgang, P., Chazot, G., Njonfang, E. and Tchoua, F. (2008) Geochemistry and Geochronology of Mafic Rocks from Bamenda Mountains (Cameroon): Source Composition and Crustal Contamination along the Cameroon Volcanic Line. Comptes Rendus Geoscience, 340, 850-857. https://doi.org/10.1016/j.crte.2008.08.008

[58] Kakar, M.I., Mahmood, K., Khan, M., Kasi, A.K. and Manan, R.A. (2013) Petrology and Geochemistry of Gabbros from the Muslim Bagh Ophiolite: Implications for Their Petrogenesis and Tectonic Setting. Journal of Himalayan Earth Sciences, 46, 19-30.

[59] Mandal, A., Ray, A., Debnath, M. and Paul, S.P. (2012) Petrology, Geochemistry of Hornblende Gabbro and Associated Dolerite Dyke of Paharpur, Puruliya, West Bengal: Implication for Petrogenetic Process and Tectonic Setting. Journal of Earth System Science, 121, 793-812. https://doi.org/10.1007/s12040-012-0195-5

[60] Maurice, A.E., Bakhit, B.R., Basta, F.F. and Khiamy, A.A. (2013) Geochemistry of Gabbros and Granitoids (M- and I-Types) from the Nubian Shield of Egypt: Roots of Neoproterozoic Intra-Oceanic Island Arc. Precambrian Research, 224, 397-411. https://doi.org/10.1016/j.precamres.2012.10.012

[61] Wang, J.P., Wang, X., Liu, J.J., Liu, Z.J., Zhai, D.G. and Wang, Y.H. (2019) Geology, Geochemistry, and Geochronology of Gabbro from the Haoyaoerhudong Gold Deposit, Northern Margin of the North China Craton. Minerals, 9, 63.

https://doi.org/10.3390/min9010063

[62] Pfander, A.J., Münker, C., Stracke, A. and Mezger, K. (2007) Nb/Ta and Zr/Hf in Ocean Island Basalts-Implications for Crust-Mantle Differentiation and the Fate of Niobium. Earth and Planetary Science Letters, 254, 158-172. https://doi.org/10.1016/j.epsl.2006.11.027

[63] Weaver, L.B. (1991) The Origin of Ocean Island Basalt End-Member Compositions: Trace Element and Isotopic Constraints. Earth and Planetary Science Letters, 104, 381-397. https://doi.org/10.1016/0012-821X(91)90217-6

[64] Condie, C.K. (2005) High Field Strength Element Ratios in Archean Basalts: A Window to Evolving Sources of Mantle Plumes? Lithos, 79, 491-504. https://doi.org/10.1016/j.lithos.2004.09.014

[65] Kuepouo, G., Tchouankoue, P.J., Nagao, T. and Sato, H. (2006) Transitional Tholeiitic Basalts in the Tertiary Bana Volcano-Plutonic Complex, Cameroon Line. Journal of African Earth Sciences, 45, 318-332. https://doi.org/10.1016/j.jafrearsci.2006.03.005

[66] Green, H.D. and O'Hara, J.M. (1971) Compositions of Basaltic Magmas as Indicators of Conditions of Origin: Application to Oceanic Volcanism. Philosophical Transactions of the Royal Society of London, 268, 707-725.

[67] Jung, S. and Masberg, P. (1998) Major- and Trace-Element Systematics and Isotope Geochemistry of Cenozoic Mafic Volcanic Rocks from the Vogelsberg (Central Germany): Constraints on the Origin of Continental Alkaline and Tholeiitic Basalts and Their Mantle Sources. Journal of Volcanology and Geothermal Research, 86, 151-177. https://doi.org/10.1016/S0377-0273(98)00087-0 
[68] Jenner, G.A., Foley, S.F., Jackson, S.E., Green, T.H., Fryer, B.J. and Longerich, H.P. (1994) Determination of Partition Coefficients for Trace Elements in High Pressure-Temperature Experimental Run Products by Laser Ablation Microprobe-Inductively Coupled Plasma-Mass Spectrometry (LAM-ICP-MS). Geochimica et Cosmochimica Acta, 57, 5099-5103. https://doi.org/10.1016/0016-7037(93)90611-Y

[69] Wang, K., Plank, T., Walker, D.J. and Smith, I.E. (2002) A Mantle Melting Profile across the Basin and Range, SW USA. Journal of Geophysical Research: Solid Earth, 107, ECV 5-1-ECV 5-21. https://doi.org/10.1029/2001JB000209

[70] Thirlwall, M.F., Upton, J.G.B. and Jenkins, C. (1994) Interaction between Continental Lithosphere and Iceland Plume-Sr-Nd-Pb Isotope Geochemistry of Tertiary Basalts, NE Greenland. Journal of Petrology, 35, 839-879. https://doi.org/10.1093/petrology/35.3.839

[71] Bogaard, F.J.P. and Wörner, G. (2003) Petrogenesis of Basanitic to Tholeiitic Volcanic Rocks from the Miocene Vogelsberg, Central Germany. Journal of Petrology, 44, 569-602. https://doi.org/10.1093/petrology/44.3.569

[72] Jenner, A.G., Dunning, R.G., Malpas, J., Brown, M. and Brace, T. (1991) Bay of Islands and Little Port Complexes, Revisited: Age, Geochemical and Isotopic Evidence Confirm Suprasubduction-Zone Origin. Canadian Journal of Earth Sciences, 28, 1635-1652. https://doi.org/10.1139/e91-146

[73] Ali, M.I., Ismail, A.I.M., Ghabria, D.S., Wahab, W.A., Eissa, M., Cazzaniga, A., Zanelli, C. and Dondi, M. (2008) Exploring Syenites from Ring Complexes in the Eastern Desert (Egypt) as Ceramic Raw Materials. Periodico di Mineralogia, 87, 67-81.

[74] Yongue, R.F., Ghogomu, T.R., Penaye, J., Ekodeck, G.E., Stendal, H. and Colin, F. (2006) Nickel and Cobalt Distribution in the Laterites of the Lomié Region, South-East Cameroon. Journal of African Earth Sciences, 45, 33-47. https://doi.org/10.1016/j.jafrearsci.2006.01.003

[75] Hiéronymus, B. (1973) Etude minéralogique et géochemique des formations bauxitiques de l'ouest du Cameroun. Cahiers ORSTOM Série Géologie, 5, 97-112. 